\title{
Yedinci Sınıf Öğrencilerinde Üstbiliş Destekli Problem Çözme Stratejileri Öğretiminin Öğrenci Başarısına ve Üstbiliş Becerilere Etkisi*
}

\section{The Effect of the Teaching of Problem Solving Strategies Supported by Metacognitive Strategies on Problem Solving Success and Metacognitive Skills of Seventh Grade Students}

\author{
Sevgi Arsuk, ${ }^{\mathrm{a}, * *}$ Dilek Sezgin Memnun ${ }^{\mathrm{b}}$ \\ ${ }^{a}$ Milli Eğitim Bakanlığı, Matematik Öğretmeni, İstanbul/Türkiye. \\ ORCID: 0000-0002-0018-2102 \\ b Bursa Uludağ Üniversitesi, Eğitim Fakültesi, Temel Eğitim Bölümü, 16059, Bursa/Türkiye. \\ ORCID: 0000-0003-3254-8858
}

\section{MAKALE BİLGİSI \\ Makale Geçmişi: \\ Başvuru tarihi: 20 Ekim 2019 \\ Düzeltme tarihi: 26 Ocak 2020 \\ Kabul tarihi: 11 Şubat 2020}

\section{Anahtar Kelimeler:}

Matematik Eğitimi

Problem Çözme Becerileri

Problem Çözme Öğretimi

Üstbiliş

Üstbiliș Becerileri

\section{A R T I C LE INFO}

\section{Article history:}

Received 20 October 2019

Received in revised form 26 January 2020

Accepted 11 February 2020

\section{Keywords:}

Mathematics Education

Problem Solving Skills

Problem Solving Teaching

Metacognition

Metacognitive Skills
ÖZ

$\mathrm{Bu}$ araştırmada, üstbiliş destekli problem çözme stratejileri öğretiminin yedinci sınıf öğrencilerinin üstbiliş becerilerine, akademik başarılarına ve problem çözme başarısına etkisinin incelemesi amaçlanmıştır. Bu amaçla, İstanbul ilinde bulunan bir ortaokulda öğrenim görmekte olan yedinci sınıf öğrencileri üç farklı gruba ayrılmıştır. Deney gruplarından birinde üstbiliş destekli problem çözme stratejileri öğretimi, ikincisinde ise yalnızca problem çözme stratejileri öğretimi yapılmıştır. Diğer taraftan, kontrol grubunda bu araştırma kapsamında bir öğretim yapılmamıștır. $\mathrm{Bu}$ öğretim sürecinin ardından, birinci deney grubunda öğrencilerin üstbiliş becerilerinin ve problem çözme başarılarının arttı̆̆ 1 raporlanmıştır. Bununla birlikte, problem çözme öğretimi alan ikinci deney grubundaki öğrencilerin yalnızca problem çözme başarılarında artış olduğu anlaşılmıştır. Kontrol grubunda üstbiliş beceri açısından da problem çözme başarısı açısından da istatistiksel olarak anlamlı düzeyde bir artı̧̧ gözlenememiştir.

\section{Giriş}

Günümüzde teknolojide meydana gelen hızlı gelişmeler, bilginin her geçen gün değişmesini ve gelişmesini

\begin{abstract}
A B S T R A C T
In this research, it was aimed to examine the effect of the teaching of problem solving strategies supported by metacognitive strategies on the seventh grade students' metacognitive skills, academic achievement and problem solving skills. With this aim, the seventh-grade students studying at a middle school in Istanbul were divided into three seperate groups. The problemsolving strategies teaching supported by metacognitive skills was applied in the first experimental group, and only the teaching of problem-solving strategies was applied in the second one. It was not given an instruction in the control group within the scope of this research. On the other hand, there was not made a teaching in control group within the scope of this research. After this teaching process, it was reported that these skills and the problem-solving success of the students were increased in the first experimental group. Besides, it was understood that there was only an increase of problem-solving success of the second experimental group in which the students were given problem solving teaching. In the control group, it was not found a statistically significant increase for the metacognitive skills or the problem-solving success of the control group.
\end{abstract}

sağlamaktadır. $\mathrm{Bu}$ nedenle, günümüz teknoloji çağında bireylerin yeni bilgiye ulaşabilmeleri ve bilgiyi kullanabilmeleri önemli hale gelmiştir (Garda ve Temizel, 2016; Şeker, 2005). Bu durum, eğitim sistemlerinde yeni ve

\footnotetext{
*Bu çalışma birinci yazarın 2019 yılında Doç.Dr. Dilek S.Memnun'un danışmanlığında Bursa Uludağ Üniversitesi Eğitim Bilimleri Enstitüsü Matematik ve Fen Bilimleri Eğitimi Anabilim Dalı'nda yürüttüğü "Yedinci Sınıf Öğrencilerine Verilen Üstbiliş Destekli Problem Çözme Öğretiminin Problem Çözme Başarısı ve Üstbiliş Becerilere Etkisi" isimli yüksek lisans tezinden türetilmiştir.

** Sorumlu yazar/Corresponding author

e-posta: sevgiarsuk@gmail.com
} 
köklü değişikleri beraberinde getirmiştir. Eğitimin temel hedefi, bireyleri hayata hazırlamak ve bireylerin bir sonraki öğrenim için yeterli donanıma sahip olmalarını sağlamaktır. Öğrencilerin akademik anlamda başarısız olma nedenlerinin başında bildiklerinin farkında olmamaları ve bildiklerini kullanamamaları gelmektedir (Baş ve Özturan-Sağırlı, 2017; Memiş ve Arıcan, 2013; Yang, \& Lee, 2013). Bu nedenle, günümüz eğitim anlayışında öğrencilerin başarılı olma yolu onların düşünmeyi öğretmekten ve düşünme kapasitesini geliştirmekten geçmektedir. $\mathrm{Bu}$ nedenle, eğitimde düşünme, analiz etme ve çözüm bulma yetenekleri yüksek, üretken bireyler yetiştirilmesi amaçlanmaktadır. Bu hedeflerin gerçekleşmesi için öğrencilerin kendi öğrenmelerinin farkında olmaları ve bunun sorumluluğunu almaları da önem arz etmektedir (Çiltaş, 2011).

Eğitim alanında özellikle de son yıllarda yapılan araştırmalarda öğrencilerin konuyu, kavramı ya da bilgiyi ne şekilde öğrendiklerine ve öğrendikleri bu bilgileri günlük yaşamlarına nasıl aktardıklarına odaklanılmaktadır. $\mathrm{Bu}$ durum, öğrencilerin eğitim-öğretim yaşamlarında gerçekleştirdikleri öğrenme süreçleri içerisindeki bilişsel ve duyuşsal davranışları da önemli kılmaktadır. Bu alanla ilişkili olarak da, öğrencilerin öğrenmeye ve öğrenilen alana yönelik inanç ve tutum gibi duygu ve düşüncelerinin yanında öz-düzenleme ve öz-yeterlik gibi farklı becerilerinin de değerlendirilmesi ihtiyacı doğmuştur (Çiltaş, 2011). Bu alanda yapılan çalışmaların bir kısmında da, öğrenme esnasında bireylerin kendi öğrenme sürecinin bilincinde olması, kendi öğrenmesini kontrol etmesi, planlaması ve süreci yönetmesine ilişkin becerilerine odaklanılmaktadır. $\mathrm{Bu}$ beceriler de araştırmacıları üstbiliş kavramına götürmektedir ve son yıllarda ortaya çıkan ve önem kazanan beceriler arasında üstbiliş de yer almaktadır. Son zamanlarda yapılan farklı araştırmalar (Kaplan, Duran ve Baş, 2016; Memiş ve Arıcan, 2013; Seçkin-Kapucu ve Öksüz, 2015) da üstbiliş, üstbiliş beceri ve üstbilişsel farkındalığı ele alınmıştır. Bu kavramlar arasından üstbiliş kavramı,"öğrenmeyi öğrenme ve kontrol altına alıp yönlendirebilme süreci" olarak açıklanabilir (Çakıroğlu, 2007: 21). Üstbiliş beceri ise "kendini izleme ve yerleştirme, hedefleri planlama ve kendi performansını değerlendirme yeteneği" olarak açıklanabilir (Özsoy, 2007: 30-31). Öğrenme ortamında ne anlatıldığını ve ne anladığını bilen, bilinçli bireyler yetiştirilmesi bakımından matematik öğretiminde etkin bir yere sahip olan bu becerilerin problem çözme ile ilişkileri aşağıda detaylı olarak açıklanmış ve araştırma bu perspektiften ele alınmıştır.

Matematik öğretiminin günümüz önemli odak noktalarından biri problem çözmedir. Matematik öğretim programlarında da problem çözme becerisi üzerinde bu kadar uzun ve detaylı durulmasının nedeni, günlük hayatta karşılaştıkları problemlere çözüm bulabilen ve problemlerin üstesinden gelebilen bireyler yetiştirmektir (Özsoy, 2014). Bireyin başarılı olması, problem çözme becerilerini geliştirerek karşılaştığı güçlükler karşısında doğru kararlar vermesi ve bu beceriyi ihtiyaç duyduğu her durumda kullanmasına bağlıdır (Sardoğan, Karahan ve Kaygusuz, 2006). Çünkü problem çözmenin tüm aşamalarında düşünme ve yönetme becerileri etkin rol oynamaktadır (Soylu ve Soylu, 2006). Bu durum da, problem çözmenin bireyin üst düzey farkındalık seviyelerinin gelişimi açısından ne kadar önemli olduğuna işaret etmektedir. Bu nedenle, çalışmaya konu olan öğretim, öğrencilerde hem akademik başarı sağlaması hem de geleceğe hazırlaması bakımından matematik dersi için önemlidir. Çünkü etkili ve kalıcı problem çözme yetisi yaşantılar sonucu gelişir ve öğrenilir (Korkut, 2002).

Farklı problem çözme türleri arasından problem çözme stratejilerinin kullanımını gerektiren rutin olmayan problemler günümüz matematik ders kitaplarında, güncellenen matematik dersi öğretim programlarında yer almaya başlamıştır. Son yıllarda matematik eğitimi alanında yapılan araştırmaların önemli bir kısmı da rutin olmayan problemlere odaklanmaktadır. Bu araştırmalar, bu problem türü için farklı sınıf düzeylerinden öğrencilerle gerçekleştirilen deneysel çalışmaları ya da bu alandaki güçlükleri ortaya koymayı amaçlayan durum çalışmalarını kapsamaktadır (Crespo, \& Kyriakides, 2007; Malloy, \& Jones, 1998; Mastromatteo, 1994; Silver, \& Cai, 1996; Yazgan, 2007; Yazgan ve Bintaş, 2005; Gür ve Hangül, 2015). Ayrıca, bu problemler öğrencilerin üst düzey analitik düşünme kabiliyetlerini sergilemek ve geliştirmek için de kullanılmaktadır (Foong, 1990; Akt. Naser, 2008). Bu problemler tek bir çözüm yolu da içermeyen problemler olup, çözülmeleri bir süreci kapsamakta ve farklı stratejileri kullanmayı gerektirmektedir (Aydurmuş, 2013). Bu stratejilerden en çok kullanılan bazı stratejiler; sistematik liste yapma, tahmin ve kontrol, diyagram çizme, tablo yapma, geriye doğru çalışma, bağıntı bulma, problemi basitleştirme ve muhakeme etme olarak ifade edilebilir.

Problem çözme becerisini etkileyen bilişsel ve duyuşsal birçok değişken olduğunu savunan çalışmalar (Akyüz ve Pala, 2010; Yıldırım, Hacıhasanoğlu, Karakurt ve Türkleş, 2011) bulunmaktadır. Bu kapsamda, yapılan incelemelerde matematik eğitiminde üstbiliş ile ilgili yapılan çalışmaların (Baykara, 2011; Çıkrıkçı ve Odac1, 2013; Durmuş ve Özdemir, 2003; Evran ve Yurdabakan, 2013; Karakelle ve Şentürk, 2006; Karsl1, 2013; Koç ve Karabağ, 2013; Oğuz ve Kutlu-Kalender, 2018; Okçu ve Kahyaoğlu, 2007; Seçkin-Kapucu ve Öksüz, 2015) bulunduğu ve yapılan çalışmaların bazılarının (Bakioğlu ve diğerleri, 2015; Baş, Sağırlı ve Bekdemir, 2016; Kaplan, Duran ve Baş, 2016; Öztürk, Akkan ve Kaplan, 2018; Serin ve Korkmaz, 2018; Yıldız ve Güven, 2016) da problem çözme ve üstbilişis birlikte ele alan çalışmalar olduğu anlaşılmıştır. Yine yapılan incelemelerden, bu araştırmaların bir kısmının (Bakioğlu ve diğerleri, 2015; Baş, Özturan-Sağırlı ve Bekdemir, 2016; Yıldız ve Güven, 2016) öğretmen ve öğretmen adayları ile bir kısmının da ortaokul öğrencileri ile gerçekleştirilen araştırmalar (Kaplan, Duran ve Baş, 2016; Serin ve Korkmaz, 2018) olduğu görülmüştür.

Öğretmenler ve öğretmen adayları ile gerçekleştirilen araştırmalardan Bakioğlu ve diğerleri (2015) tarafindan yapılan çalışmanın sonucunda, teknoloji tutumu ile üstbiliş farkındalık ve problem çözme becerileri arasında pozitif; üstbiliş farkındalık ile problem çözme becerileri arasında da yine pozitif yönde anlamlı ilişkiler olduğu rapor edilmiştir. Ayrıca, fen bilgisi öğretmenlerinin üstbiliş farkındalık düzeylerinin sınıf öğretmenlerine kıyasla daha yüksek olduğu da ortaya koyulmuştur. Baş, Özturan-Sağırlı ve Bekdemir (2016) tarafından ortaokul matematik öğretmen adaylarının üst biliş farkındalık, problem çözmeye yönelik tutum ve matematik problemi çözmeye ilişkin inançları arasında pozitif ilişki bulunduğu açıklanmıştır. Ayrıca, bu 
öğrencilerin inanç, tutum ve üstbiliş düzeyleri arasında sınıf seviyelerine göre istatistiksel olarak anlamlı farklılıklar bulunmadı̆̆ı da çalışmanın sonucunda ifade edilmiştir. Yildız ve Güven (2016) tarafindan, matematik öğretmenlerinin en kisıtlı olarak problemi anlama aşamasında, öğrencilerinin üstbiliş davranışlarını harekete geçiren davranışlar sergiledikleri açıklanmıştır. Ayrıca, öğrencilerin problemi kendi cümleleri ile ifade etmelerini istemenin ardından kendilerinin problem metni ile tutarlılı̆̆ını kontrol etmeyi isteme davranıșında bulunmadıkları da çalışmanın sonucunda ortaya koyulmuştur.

Ortaokul düzeyinde Kaplan, Duran ve Baş (2016) tarafından yapılan araştırmanın sonucunda, ortaokul öğrencilerinin problem çözme beceri algısı ile matematiksel üstbiliş farkındalıkları arasında pozitif yönde anlamlı bir ilişki bulunduğu açıklanmıştır. Öztürk, Akkan ve Kaplan (2018) tarafından yapılan çalışmanın sonucunda ise, öğrenim seviyesi arttıkça üstün yetenekli ortaokul öğrencilerinin problem çözme süreçlerinde sergiledikleri üst bilişsel becerilerin sayısında artış olduğu rapor edilmiştir. Ayrıca, öğrencilerin en az sergiledikleri üst bilişsel beceriler olarak problemi kendi cümleleriyle ifade edme ve yazma (anlama), yazılı çözüm yapmadan veya planı uygulamadan önce zihninden çözüm yapma (planlama), yanlışı fark etme ve yeni bir yaklaşım belirleyebilme (uygulama) ve farklı çözüm yöntemlerini düşünme (değerlendirme) şeklinde sıralanmıştır. Serin ve Korkmaz (2018) ise yaptıkları çalışmanın sonucunda, işbirlikli öğrenmeye dayalı sınıf ortamlarında uygulanan üstbilişsel becerileri incelemeye yönelik uygulamaların dördüncü sınıf öğrencilerinin problem çözme becerilerinde etkili olduğunu açıklamışlardır.

Yapılan bu araştırmalardan hareketle problem çözme aşamasında etkili olan düşünmenin üst biliş odaklı bir öğretim süreci ile mümkün olabileceği söylenebilir. Başka bir ifadeyle, üstbilişin problem çözme sürecinde bir yol gösterici olarak rol aldığı söylenebilir (Azak, 2015). Üstbilişsel becerilerin problem çözme becerisini ve sürecini olumlu yönde etkilediği de bazı araştırmalarda (Flavell, 1976; Özsoy, 2007) ifade edilmektedir. Ayrıca, okumanın zihinsel bir etkinlik olarak tanımlanması ve alg1, anlamlandırma, kavrama ve yorumlamayla bütünleştirilmesi, okumaya üst düzey bir anlam yüklenildiğine ve üstbilişle bağlantısı bulunduğuna işaret etmektedir. $\mathrm{Bu}$ nedenle, okuduğunu anlama ve yorumlama becerisi problem çözme başarısını etkileyen değişkenlerden biri olarak ortaya çıkmaktadır. Buradan hareketle, bu çalışmada öğrencileri problem çözme başarıları ile üstbiliș farkındalık ve okuma stratejileri üstbiliş farkındalık düzeyleri bir arada ele alınacaktır. Buradan hareketle, bu araştırmada üstbiliş destekli problem çözme stratejileri öğretiminin yedinci sınıf öğrencilerinin üstbiliș becerilerine, akademik başarılarına ve problem çözme başarısına etkisinin incelemesi amaçlanmıştır. Bu amaçla, aşağıda yer alan araştırma problemlerine cevap aranmaya çalışılmıştır:

1. Ortaokul yedinci sınıf öğrencilerine verilen üstbiliş destekli olan / olmayan problem çözme stratejileri öğretimi, öğrencilerin matematik başarıları açısından istatistiksel olarak anlamlı düzeyde farklılıklar oluşturmakta mıdır?
2. Ortaokul yedinci sınıf öğrencilerine verilen üstbiliş destekli olan / olmayan problem çözme stratejileri öğretimi, öğrencilerin problem çözme başarıları açısından istatistiksel olarak anlamlı düzeyde farklılıklar oluşturmakta mıdır?

3. Ortaokul yedinci sınıf öğrencilerine verilen üstbiliş destekli olan / olmayan problem çözme stratejileri öğretimi, öğrencilerin üstbiliş farkındalıkları açısından istatistiksel olarak anlamlı düzeyde farklılıklar oluşturmakta mıdır?

4. Üstbiliş destekli olan / olmayan problem çözme stratejileri öğretimi verilen ortaokul yedinci sınıf öğrencilerinin problem çözme başarıları ile üstbiliş farkındalıkları arasında istatistiksel olarak anlamlı düzeyde ilişkiler var mıdır?

5. Ortaokul yedinci sınıf öğrencilerine verilen üstbiliş destekli olan / olmayan problem çözme stratejileri öğretimi, öğrencilerin okuma stratejileri üstbiliş farkındalıkları açısından istatistiksel olarak anlamlı düzeyde farklılıklar oluşturmakta mıdır?

6. Üstbiliş destekli olan / olmayan problem çözme stratejileri ögretimi verilen ortaokul yedinci sinıf öğrencilerinin problem çözme başarıları ile okuma stratejileri üstbiliş farkındalıkları arasında istatistiksel olarak anlamlı düzeyde ilişkiler var mıdır?

$\mathrm{Bu}$ araştırma kapsamında yapılan uygulamaları problem çözme strateji öğretiminin üstbiliş destekli olan ve olmayan biçimde gerçekleştirilecek olup bu yönüyle araştırma yapılan benzer araştırmalardan farklılık göstermektedir.Ayrıca, bu çalışmanın matematik eğitimine öğrenci başarısının artmasını sağlama açısından da önemli katkısı olacağı düşünülmektedir.

\section{Yöntem}

$\mathrm{Bu}$ bölümde araştırmanın modeline, çalışmaya katılan öğrencilere ilişkin bilgilere, bu öğrencilerin üstbiliş beceri ve farkındalıkları ile problem çözme başarılarının incelenmesi amacıyla araştırma kapsamına alınan veri toplama araçlarına, araştırmanın amacına uygun biçimde gerçekleştirilen uygulamalara, bu uygulamalar öncesinde ve sonrasında yapılan analizlere ilişkin detaylı açıklamalara yer verilmiştir.

\subsection{Araştırma Modeli}

$\mathrm{Bu}$ çalışmada, araştırmaya katılan ortaokul yedinci sınıf öğrencilerinde üstbiliş destekli olan ve olmayan problem çözme stratejileri öğretiminin öğrenci başarısına ve üstbiliş becerilere etkisi incelenmiştir. Bu nedenle, bu araştırmada "ön test-son test kontrol gruplu yarı deneysel desen" araştırma modeli tercih edilmiştir. "Değişkenler arasındaki neden-sonuç ilişkilerini tespit etmek için kullanılan araştırma deseni" deneysel deseni oluşturmaktadır (Büyüköztürk, 2007). Yarı deneysel araştırma modelinde ise, deneysel desenden farklı olarak kontrol ve deney grupları rastgele olarak değil de ölçümlerle belirlenmekte ve gruplar üzerinde eşleştirme yapılmaktadır (Büyüköztürk, 2007; Ekiz, 2003). Bu çalışmada yer alan uygulama grupları oluşturulurken rastgele biçimde seçilmemiştir. Araştırmanın kapsamlı olması ve detaylı karşılaştırmalara yer verecek olması nedeni ile, araştırma grupları uygulaması yapılan ön testleri arasında istatistiksel olarak anlamlı farklılıklar bulunmayacak yani test sonuçları birbirine eşit sayılacak şekilde yakın olarak belirlenmiştir. 


\section{2. Çalışma Grupları}

Bu çalışma, 2018-2019 eğitim öğretim y1lında İstanbul ili Arnavutköy ilçesindeki bir devlet okulunda yedinci sınıfta öğrenim görmekte olan, çalışmaya katılma konusunda istekli ve veli izni alınan öğrenciler ile gerçekleştirilmiştir. Araştırma ortalama bir devlet okulunda, ebeveynlerinin eğitim düzeyleri çoğunlukla ilkokul ya da ortaokul olan öğrenci grubu ile yürütülmüştür. Bu kapsamda, araştırma kapsamına alınan öğrencilerin annelerinin 40'ı ilkokul, 29'u ortaokul ve 4'ü ise lise mezunudur. Benzer şekilde, öğrencilerin babalarının 34'ü ilkokul, 24'ü ortaokul ve 15'i ise lise mezunudur. Araştırma kapsamında uygulamaların yapılması için resmi izinlerin alınmasının ardından, öğrencilere araştırma için belirlenen ölçek ve anketler ön testler şeklinde uygulanmıştır. Elde edilen bu veriler için "matematik başarı testi" üzerinden yapılan grup denklikleri kontrolünden hareketle, araştırmaya deney ve kontrol gruplarında katılacak olan ögrenciler (Deney1, Deney2 ve Kontrol grupları için sırasıly 25,24 ve 24) toplam 73 öğrenci olarak belirlenmiş̧ir. Çalışmaya katılan bu öğrencilerin 32 'si (\%43.8) kız ve 41'i (\%56.2) ise erkek öğrencidir. Ayrıca gruplar bazında ele alındığında, 14 (\%56) kız ve $11(\% 44)$ erkek öğrenci Deneyl grubunda araştırmaya katılmıştır. Benzer şekilde, 12 (\%50) kız ve 12 (\%50) erkek öğrenci Deney2 grubunda, $11(\% 45.8)$ kız ve 13 (\%54.2) erkek öğrenci ise Kontrol grubunda araştırmaya katılmıştır. Bu kapsamda, araştırmaya katılmak üzere deney ve kontrol gruplarını oluşturacak biçimde matematik başarı puanları ve problem çözme ön testi açısından denk gruplar oluşturulmuş ve bu denklik aşamalarına ilişskin detaylı bilgilere de Bulgular kısmında yer verilmiştir.

\subsection{Veri Toplama Araçları}

$\mathrm{Bu}$ araştırmanın amaçları doğrultusunda, İl Milli Eğitim Müdürlüğ̈̈'nün 06.06.2018 tarihli 59090411-44E.11027204 sayılı izninin (Ek 2) alınmasının ardından yedinci sınıf öğrencilerine uygulanan dört farklı ölçme aracı üzerinden araştırma verileri toplanmıştır. Kullanılan bu testlere ve anketlere ilişkin detaylı bilgileri aşağıda yer almıştır.

\subsubsection{Matematik Başarı Testleri}

Öğrencilerin mevcut başarısını ortaya koymak amacıyla yedinci sınıfların ders kazanımları incelenmiş ve konuyla ilgili ders kitapları ve geçmiş yıllarda yapılan merkezi sınavlarda çımış sorulardan oluşturulan soru havuzundan yirmişer soruluk ön test ve son test için iki farklı başarı testi hazırlanmıştır. Bu soru havuzu içerisinden, öğrenci başarı durumunu ölçecek şekilde kapsam geçerliliğine sahip çoktan seçmeli sorulardan oluşan test taslakları hazırlanmıştır.

Testin kapsam geçerliliğini sağlamak amacıyla hazırlanan belirtke tablosu ile soru dağılımı kazanım sürelerine uygun olarak dağıtılmıştır. Matematik başarı testi, ön ve son testler olarak uygulanabilmesi için kapsam ve seviye olarak birbirlerine yakın sorulardan oluşan iki farklı sınav biçiminde hazırlanmıştır. Ardından, testlerin uygunluğu konusunda üç ortaokul matematik öğretmeninin görüşü alınmıştır. Bu kapsamda, testleri inceleyen öğretmenler hazırlanmış olan bu testlerde, yedinci sınıfın ilk dönemi için matematik ders programlarında yer alan kazanımların tamamına, programda yer alan ders saat sayıları oranında yer verildiğini onaylamışlardır. Aynı zamanda, bu öğretmenler söz konusu testlerde yer alan tüm sorulardaki şılarının birbiri ile uyumlu olacak şekilde küçükten büyüğe ya da büyükten küçüğe sıralanmasını ve testte ardı ardına aynı şıkların doğru seçenek olarak yer almamasını önermiş̧lerdir. $\mathrm{Bu}$ inceleme esnasında, öğretmenlerden biri testlerden birinde bir soru için hazırlanmış olan şeklin bulanık olduğunu ifade etmiştir. Bununla birlikte, diğer iki öğretmen de anlaşılabilirliği arttırmak adına bir soruda soru cümlesi için bir düzeltme önermişlerdir. Yapılan bu düzeltmelerin ardından testler araştırma için hazır hale gelmiştir ve araştırma gruplarında uygulanmıştır. Ardından da, testler için öncelikle benzer özelliklere sahip bir okulun toplam 20 yedinci sınıf öğrencisi ile bir pilot uygulama yapılmıştır.

Hazırlanan matematik başarı testleri için, cevap kâğıtlarında bulunan her bir doğru cevap (5), yanlış ve alakasız cevaplar ise (0) olarak kodlanmıştır. Bu durumda, matematik başarı testlerinden alınabilecek en yüksek puan 100 en düşük puan ise 0 olarak hesaplanmıştır. Testin güvenilirliği için Kuder Richardson-21 güvenilirlik katsayısı 0.75 olarak belirlenmiştir. Güvenilirlik 0.60-0.90 aralığında olduğunda test güvenilir kabul edilmektedir (Bolat ve Karamustafaoğlu, 2019).

\subsubsection{Problem Çözme Testleri}

$\mathrm{Bu}$ araştırmada, öğrencilerin mevcut problem çözme başarılarını ortaya koymak için öğrencilere yöneltilmek üzere onar soruluk iki adet problem çözme testi hazırlanmıştır. Problem testi hazırlanmadan önce yedinci sınıf ders kazanımları incelenmiş ve seviyeye uygun olarak ders kitapları ve geçmiş yıllardaki merkezi sınavlarda çıkmış sorulardan 200 soruluk bir soru havuzu oluşturulmuştur. Bu soru havuzu içerisinden, öğrencilerin mevcut durumunu ölçecek problemlerden oluşan test taslakları hazırlanmıştır. $\mathrm{Bu}$ aşamada, farklı problem çözme stratejilerini kullanabilecekleri problemler bir araya getirilerek test taslakları oluşturulmuştur. Sonuç olarak, problem çözme testinin ön ve son test biçiminde uygulanabilmesi için kapsam ve seviye olarak birbirlerine yakın sorulardan oluşan iki farklı sınav hazırlanmıştır.

Başarı testinin güvenirliğini sağlamak amacıyla örneklem ile benzer özelliklere sahip bir okulda pilot uygulama yapılmıştır. Ayrıca iki matematik öğretmenin görüşü de uzman görüşü olarak alınmıştır. Hazırlanan problem çözme başarı testlerinde cevap kâğıtlarında bulunan her bir doğru cevap (2), hatalı cevaplar (0) ve eksik cevaplar da (1) olarak kodlanmıştır. Problem çözme testlerinden alınabilecek en yüksek puan 20 ve en düşük puan ise 0 olarak hesaplanmıştır. Yapılan uygulamalar sonucunda, problem çözme ön ve son testleri için KR-21 güvenilirlik katsayısı sırasıyla .76 ve .71 olarak hesaplanmıştır. Bu durum, testin güvenilir bir test olduğuna işaret etmektedir.

\subsection{3. Üstbiliş Farkındalık Envanteri}

Araştırmada, üstbiliş farkındalığı değerlendirebilmek için Schraw, \& Dennison (1994) tarafından geliştirilen Üstbiliş Farkındalık Envanteri kullanılmıştır. Türkçe'ye uyarlama çalışması Akın, Abacı ve Çetin (2007) tarafından yapılmıştır. Toplam 52 maddeden oluşan bu ölçek "Hiç bir zaman - 1 puan, Nadiren - 2 puan, Sik sik - 3 puan Genellikle - 4 puan ve Her zaman - 5 puan" şeklinde beşli 
likert tipinde hazırlanmış ve puanlanmıştır. Bu envanterin orijinal hali iki temel boyut altında yer alan sekiz alt faktörden oluşmaktadır. Temel boyutlardan birincisi olan bilişin bilgisi altında; açıklayıcı bilgi, prosedürel bilgi ve durumsal bilgi olmak üzere üç alt boyut yer alırken; bilişin düzenlenmesi boyutu ise planlama, izleme, değerlendirme, hata ayıklama ve bilgi yönetme olmak üzere beş alt boyuta sahiptir (Schraw, \& Dennison, 1994). Akın, Abacı ve Çetin (2007) tarafindan envanterin dilsel eş değerliğini belirlemek amacıyla İngilizce ve Türkçe form puanları arasındaki korelasyonları hesaplanmış ve korelasyonun ölçeğin tümü için .93 olduğu görülmüştür. Yapılan uygulamalar sonucunda, bu araştırma için Üstbiliş farkındalık Envanteri Cronbach alfa değerleri ön ve son uygulama için sirasıyla .932 ve .929 olarak hesaplanmıştır. "Cronbach Alfa değeri 0.00 ile 0.40 arasında ise güvenilir değil, 0.40 ile 0.60 arasında ise düşük düzeyde güvenilir, 0.60 ile 0.80 arasında ise güvenilir, 0.80 ile 1 arasında ise yüksek derecede güvenilir bir ölçek olarak yorumlanmaktadır." (Özdamar, 2004: 633). Bu durumda, ölçeğin bu araştırma için yapılan uygulamaları ölçeğin güvenilir bir ölçek olduğuna işaret etmektedir.

\subsubsection{Okuma Stratejileri Üstbiliş̧ Farkındalık Ölçeği}

Okuma stratejileri üstbilişsel farkındalığının ölçülmesi amacıyla, çalışmada Mokhtari ve Reichard tarafindan 2002 yılında geliştirilen ve Türkçeye uyarlama çalışması Öztürk tarafindan 2012 yılında yapılan Okuma Stratejileri Üstbilişsel Farkındalık Envanteri kullanılmıştır.

Ölçeğin tamamı için Cronbach Alfa değeri .93 olarak bulunmuştur. $\mathrm{Bu}$ ölçeğin tamamı için iç tutarlılık değerleri ise $.75^{\prime}$ den yüksek bulunmuştur ki, bu durum da ölçeğin güvenirlik değerlerinin yüksek olduğunu göstermektedir. Ölçeğin toplam puanı ile alt faktör puanları arasındaki korelasyonları .86 ile .96 $(\mathrm{p}<.01)$ arasında değişmektedir. $\mathrm{Bu}$ araştırma kapsamında yapılan uygulamalar sonucunda da, bu araştırma için Okuma Stratejileri Üstbiliş Farkındalık Envanteri için Cronbach Alfa değerleri ön uygulama ve son uygulama için sırasıyla .907 ve .917 olarak hesaplanmıştır.

\subsection{Uygulama Süreci ve Verilerin Toplanmas 1}

Uygulamalar, 2018-2019 eğitim-öğretim yılı ikinci dönemi içerisinde Deney1 ve Deney2 gruplarında toplam 9 hafta (9x2=18 ders saati) süresince yapılmıştır. Uygulamalar okul saatleri dışında haftalık iki ders süresi boyunca gerçekleştirilmiştir. $\mathrm{Bu}$ iki grupta her hafta bir problem çözme stratejisinin öğretimi yapılmıştır. Aşağıda haftalık olarak hangi stratejilerin uygulandığını gösteren strateji listesine yer verilmiştir:

1. Hafta: Tahmin ve Kontrol Etme

2. Hafta: Şekil Çizme

3. Hafta: Sistematik Bir Liste Oluşturma

4. Hafta: Örüntü Arama

5. Hafta: Geriye Doğru Çalışma

6. Hafta: Problemi Basitleştirme

7. Hafta: Denklem Kurma/Eşitlik Yazma

8. Hafta: Akıl Yürütme-Muhakeme Etme

9. Hafta: Rutin problemler

Öğretimi planlanan her yeni problem çözme stratejisi için uygun olarak belirlenen problemlerin birden çok strateji kullanımını gerektirmesi durumunda, bu strateji ya da stratejilerin daha önce öğretimi yapılan stratejiler olmasına da dikkat edilmiştir (Yazgan ve Bintaş, 2005). Bu stratejilerin yer aldığı örnek problemlere de Ek 1'de yer verilmiştir.

Deney1 grubunda, üstbiliş stratejilerin desteklendiğ $i$ bir problem çözme öğretimi uygulanmıştır. $\mathrm{Bu}$ kapsamda, öğrenciler problem çözme sürecinde üstbilişsel yönlendirme ile problemler eşliğinde çözüm yoluna ulaşmışlardır. Problem çözme sürecinde üstbilişsel becerileri geliştirmek amacıyla Yaşa (2010) tarafindan hazırlanmış ve kullanılmış olan sorular çalışma kapsamına alınmış ve uygulamalarda kullanılmıştır. $\mathrm{Bu}$ sorular, öğrencileri üstbiliş becerilerini kullanmaya yönlendirme amaciyla hazırlanmış olan sorulardır. Yapılan uygulamaların sonunda, araştırmaya Deney1 grubunda katılan her bir öğrenciden kendisi ile sıra arkadaşının geçirdiği düşünme süreçlerini ve problem çözümlerini gözden geçirmeleri ve değerlendirmeleri istenmiştir. Her bir problemin çözümünden sonra, gönüllü öğrencilerden çözüm yollarını ve takip ettikleri süreci açıklamaları istenmiştir. Sonuca ulaştıktan sonra da, öğrencilerden "Soruyu farklı bir yolla daha çözebilir miydiniz?" biçimindeki soruyu cevaplamak için düşünmeleri istenmiştir. Ayrıca, her bir problemin çözümünden sonra öğrenciler konu ile ilgili önemli bilgileri ve çözümleri not almışlardır. Sonraki aşamada ise, farklı çözüm yolları tartışılmıştır. Aynı zamanda, dersin sonunda o haftanın problem çözme stratejisi hakkında kısa bilgilere de yer verilmiştir. Öğrencilerin çözüm kâğıtları çalışma sonunda öğretmen tarafindan inceleme amaçlı toplanmıştır.

Çalışma kapsamında, Deney1 grubunda gerçekleştirilen uygulamalarda yer alan problemler Deney2 grubunda yapılan uygulamalarda da kullanılmıştır. Deney2 grubunda yalnızca problem çözme stratejileri ögretimine yer verilmiştir. $\mathrm{Bu}$ grupta yapılan çalışmalarda öğrencilerin aktif katılımları sağlanmış, soru-cevap ve tartışma gibi yöntemler kullanılmıştır. Öğrencilerden kendilerine verilen çalışma kağıdına çözümü yazmaları istenmiştir. Ardından, sınıf tartışma ve çözümün anlatımı ile her bir uygulama tamamlanmıştır. Bununla birlikte, öğrencilerin düşünme süreçlerini açı̆̆a çıkaracak ya da üstbilişsel kontrol ve üstbilişsel becerilerini geliştirecek bir çalışma yapılmamıştır. Ayrıca dersin sonunda, o haftanın problem çözme stratejisi hakkında kısa bilgilere de yer verilmiştir. Öğrencilerden çalışma sonunda çözüm kâğıtları öğretmen tarafindan incelenmek üzere toplanmıştır.

Kontrol grubundaki öğrencilerle ise, araştırmacı tarafından matematik dersi programlarına uygun olarak matematik dersleri yapılmaya devam etmiştir. Bu gruptaki öğrencilerle araştırma kapsamında ayrıca uygulama yapılmamıştır. Sonuç olarak, araştırmanın deney1-2 ve kontrol grubu ile gerçekleştirilen uygulamalarda, araştırmanın unsurları üzerinde bağımlı değişkenlerin bağımsız değişkenlere etkisi incelenmiştir. Aşağıda uygulama süreci ile ilgili bilgiler öncelikle tablo ve tabloya ilişkin bilgiler ile açıklanmıştır.

Tablo 1. Araştırmadaki Uygulama Süreci

\begin{tabular}{cclcc}
\hline Gruplar & ÖnTest & İşlem & SonTest \\
\hline Deney1 & O1 & Üstbiliş Beceri Destekli Problem & S1 \\
Çözme Stratejileri Öğretimi & S2 \\
Keney2 & O2 & Problem Çözme Stratejileri Öğretimi & S3 \\
\hline
\end{tabular}

$\mathrm{Bu}$ araştırma sürecinde, dört farklı veri toplama aracı uygulama öncesinde ön test şeklinde uygulanmıştır. 
Uygulamalar kapsamında da, Deneyl grubunda üstbilişsel stratejilerle destekli problem çözme strateji öğretimi, Deney2 grubunda yalnızca problem çözme strateji öğretimi yapılmıştır. Yapılan uygulamalar için öğrenciler ikişerli çalışma gruplarına ayrılmış ve böylelikle problemlerin çözümü konusunda tartışmaları ve kolay bir şekilde doğru çözüme ulaşmaları hedeflenmiştir. Çalışmada gruplar oluşturulurken, öğrencilerin birbirleri ile olan etkileşimleri ve birlikte çalışmalarına yönelik öngörüleri de göz önünde tutulmuştur. Böylece de, öğrencilerin araştırma gruplarında çalışmaya hazır olmaları ve problemler konusunda birlikte çalışmaları sağlanmıştır. Uygulamalarda, öğretmenin görevi problemlerle meşgul olmaları için katılımcıları cesaretlendirmek ve yönlendirmekle sınırlı kalmıştır. Kontrol grubu ile herhangi bir uygulama yapılmamıştır.

\subsection{Verilerin Analizi}

$\mathrm{Bu}$ araştırma kapsamında, Araştırma ve Yayın Etiği'ne uyularak yapılan uygulamalar sonucunda ulaşılan verilerin analizi, nicel analiz yöntemleri üzerinden gerçekleştirilmiştir. Nicel analizler, önceden belirlenmiş amaçlara ulaşmak amacıyla verilerin toplanmasını, bu verilerin analizi sonucunda bulguların ortaya çıkarılmasını kapsamaktadır.

$\mathrm{Bu}$ kapsamda özellikle de betimsel analize yer verilmiştir. Betimsel analizde amaç, bulguların düzenlenerek ve sistematik, detaylı bir biçimde betimlenerek yorumlanması, neden-sonuç ilişkilerinin detaylı bir şekilde incelenmesi ve belirli sonuçlara ulaşılmış bir şekilde okuyucuya sunulmasıdır. (Yıldırım ve Şimşek, 2005: 224). Bu kapsamda, öncelikle araştırmada yer alan iki farklı deney gruplarının (Deney1 ve Deney2) ve bir de Kontrol grubunun denkliğine bakılmıştır. Bu aşamada, öğrencilerin araştırma kapsamına alınan ölçek ve testlerden elde edilen puan ortalamalarının normallik varsayımının test edilmesinde Shapiro Wilk's Testi istatistiğinden faydalanılmıştır. Ne şekilde puanlandırıldığı veri toplama araçları kısmında açıklanmış olan matematik başarı ve problem çözme testleri için toplam puanlar hesaplanmıştır. Ardından, veriler için analizler yapılırken Shapiro Wilk's testi sonuçlarına göre normal dağılım gösteren verilerde parametrik test teknikleri, normal dağılım sahip olmayan verilerin analizlerinde ise parametrik olmayan test teknikleri kullanılmıştır. Elde edilen verilerin analizinde; bağımsız/bağımlı örneklem t-testi, Mann Whitney-U testi ile Spearman/Pearson Korelasyon analizleri kullanılmıştır.

$\mathrm{Bu}$ çalışmada yapılan istatistiksel analiz sonuçları .05 anlamlılık düzeyinde değerlendirilmiştir. Korelasyonu yorumlamada, $\quad 0.70-1.00$ arasında yüksek, 0.70-0.30 arasında orta ve 0.30-0.00 arasında olması ise düşük düzeyde bir ilişki bulunduğu kabul edilmiştir (Büyüköztürk, 2007). Bu kısımda, veri toplama araçları ile elde edilen verilerin analizinde SPSS 13.0 Paket Programı ile Microsoft Excel programından yararlanılmıştır.

\section{Bulgular}

$\mathrm{Bu}$ araştırmada, yedinci sınıfta üstbiliş destekli problem çözme stratejileri öğretiminin üstbiliş becerilere, akademik başarılara ve problem çözme başarısına etkisinin incelemesi amaçlanmıştı. Bu kapsamda, bu kısımda ilk olarak Deney1, Deney2 ve Kontrol gruplarının denkleştirilme aşamalarına ilişkin detaylı bilgilere yer verilmiştir. Ardından da, Deney1 ve Deney2 gruplarında gerçekleştirilen problem çözme öğretimi ile Deney1, Deney2 ve Kontrol gruplarında yapılan test ve anket uygulamaları sonucunda elde edilen bulgulara yer verilmiştir.

\subsection{Grupların Belirlenmesi için Denklik Çalışmaları}

$\mathrm{Bu}$ kısımda, deney ve kontrol gruplarının belirlenmesi amacıyla matematik başarı ve problem çözme ön test puanları üzerinden yapılan denkleştirme çalışmalarına yer verilmiştir. Bu kapsamda, aşağıda yer alan tablolarda bu veriler üzerinden yapılan detaylı analizlere yer verilmiştir.

Tablo 2. Deney ve Kontrol Gruplarının Matematik Başarı Puanlarının Normal Dağılımına ilişkin Analiz Sonuçları

\begin{tabular}{lcccc}
\hline Gruplar & $\mathrm{n}$ & $\bar{x}$ & ss & Shapiro-Wilks(p) \\
\hline Deney1 & 25 & 11.60 & 4.40 & .193 \\
Deney2 & 24 & 11.91 & 4.26 & .339 \\
Kontrol & 24 & 11.29 & 3.99 & .183 \\
\hline$* \mathrm{p}<.05$ & & & &
\end{tabular}

Tablo 2'de görüldüğü üzere, deney ve kontrol gruplarının ön test matematik başarı puanlarından elde edilen verilerin analizi sonucunda ulaşılan bilgilere göre grupların normal dağılım gösterdiği anlaşılmıştır ( $\mathrm{p}>.05)$. Araştırma kapsamına alınan araştırma gruplarına ait verileri normal dağılım gösterdiği için bu verilere bağımsız örneklem t-testi uygulanabileceği kararlaştırılmıştır. Grupların ön test matematik başarı puanlarına ilişkin veriler arasında istatistiksel olarak anlamlı farklılık bulunup bulunmadığını gösteren bağımsız örneklem t-testi sonuçlarına da Tablo 3 'te yer verilmiştir.

Tablo 3. Grupların Ön Test Matematik Başarı Puanlarına ilişskin Bağımsız Örneklem t-testi Sonuçları

\begin{tabular}{lcrccc}
\hline Gruplar & $\mathrm{n}$ & $\bar{x}$ & $\mathrm{ss}$ & $\mathrm{t}$ & $\mathrm{p}$ \\
\hline Deney1 & 25 & 11.60 & 4.46 & & \\
Kontrol & 24 & 11.29 & 3.99 & 0.504 & .617 \\
\hline Deney2 & 24 & 11.91 & 4.26 & & \\
Kontrol & 24 & 11.29 & 3.99 & 0.314 & .755 \\
\hline$* \mathrm{p}<.05$ & & & & &
\end{tabular}

Buradan anlaşılacağı üzere, Deney1 ve Kontrol gruplarının ön test matematik başarı puanları incelendiğinde istatistiksel olarak anlamlı düzeyde bir farklılık görülmemektedir $\left(t_{\text {Deney1-Kontrol }}(47)=0.504 ; \mathrm{p}>.05\right)$. Benzer şekilde, Deney2 ve Kontrol gruplarının başarı puanları arasında da istatistiksel olarak anlamlı düzeyde bir farklılığa ulaşılamamıştır $\left(\mathrm{t}_{\text {Deney2-kontrol }}(47)=0.314 ; \mathrm{p}>.05\right)$. Deney1/Deney2 ve Kontrol gruplarının ortalamaları incelendiğinde de, Deney1 ve Kontrol gruplarının matematik başarı puanlarının birbirlerine oldukça yakın olduğu da görülmüştür.

Araştırma gruplarının problem çözme testi puanlarının denkliğine bakılması amacıyla da, grupları oluşturan öğrencilerin ön test problem çözme başarı puanlarının normal dağılım gösterip göstermediği yine Shapiro Wilk's Testi ile analiz edilmiştir (Tablo 4).

Tablo 4. Grupların Ön Test Problem Çözme Testi Başarı Puanlarının Normal Dağılımına ilişkin Analiz sonuçları

\begin{tabular}{lcccc}
\hline Gruplar & $\mathrm{n}$ & $\bar{x}$ & SS & Shapiro-Wilks (p) \\
\hline Deney1 & 25 & 8.88 & 5.15 & .492 \\
Deney2 & 24 & 7.00 & 4.30 & .381 \\
Kontrol & 24 & 8.13 & 4.74 & .526 \\
\hline * $<<05$ & & & &
\end{tabular}


Tablo 4'ten anlaşılacağı gibi, araştırma gruplarının problem çözme testi puanlarından elde edilen verilerin analizi sonucunda ulaşılan bilgilere göre, araştırma kapsamına alınan üç grubun da normal dağılım gösterdiği anlaşılmıştır (p>.05). Bu nedenle de, bu verilere bağımsız örneklem t-testi uygulanabileceği kararlaştırılmıştır.

$\mathrm{Bu}$ gruplara ilişkin ön test problem çözme başarı puanları arasında istatistiksel olarak anlamlı farklılı bulunup bulunmadığını gösteren bağımsız örneklem t-testi sonuçları da aşağıdaki tabloda sunulmuştur.

Tablo 5. Grupların Ön Test Problem Çözme Testi Başarı Puanlarına İlişkin Bağımsız Örneklem t-testi Sonuçları

\begin{tabular}{lccccc}
\hline Gruplar & $\mathrm{n}$ & $\bar{x}$ & $\mathrm{SS}$ & $\mathrm{t}$ & $\mathrm{p}$ \\
\hline Deney1 & 25 & 8.88 & 5.33 & \multirow{2}{*}{0.315} & \multirow{2}{*}{.517} \\
Kontrol & 24 & 8.13 & 4.74 & & \\
\hline Deney2 & 24 & 7.00 & 4.30 & \multirow{2}{*}{0.860} & .394 \\
Kontrol & 24 & 8.13 & 4.74 & & \\
\hline$* \mathrm{p}<.05$ & & & & &
\end{tabular}

Tablo 5 'te görüldüğü üzere, Deney1 ve Kontrol gruplarının uygulama öncesi problem çözme testi başarı puanları incelendiğinde istatistiksel olarak anlamlı düzeyde bir farklılığa ulaşılamamıştır $\quad\left(\mathrm{t}_{\text {Deney1-Kontrol }}(47)=0.315 ; \mathrm{p}>.05\right)$. Deney1 ve Kontrol gruplarının ortalamaları incelendiğinde de, Deney1 ve Kontrol gruplarının problem çözme testi başarı puanlarının birbirlerine oldukça yakın olduğu da görülmüştür. Benzer şekilde, Deney2 ve Kontrol gruplarının uygulama öncesi başarı puanları incelendiğinde de, bu gruplardaki öğrencilerin problem çözme testi başarı puanları arasında yine istatistiksel olarak anlamlı düzeyde bir farklılığa ulaş1lamamıştır $\quad\left(t_{\text {Deney2-kontrol }}(46)=0.860\right.$; $\mathrm{p}>$.05). Buradan hareketle, Deney2 ve Kontrol gruplarında araştırmaya katılan öğrencilerin problem çözme testi başarı puanlarının da yine birbirlerine yakın olduğu anlaşılmıştır.

Elde edilen analiz sonuçlarına göre, deney ve kontrol gruplarının matematik başarı ve problem çözme başarıları açısından istatistiksel olarak birbirine denk oldukları söylenebilir. Ulaşılan bu sonuçlar da, araştırmaya katılan yedinci sınıf öğrencilerinin uygulamaya başlamadan önce problem çözme başarısı açısından birbirlerine denk olduğu için araştırmaya uygun olduğunu göstermektedir.

\subsection{Matematik Başarı Durumları}

Araştırma kapsamına alınan birinci araştırma problemi "Ortaokul yedinci sınıf ögrencilerine verilen üstbiliş destekli olan / olmayan problem çözme stratejileri öğretimi, öğrencilerin matematik başarları açısından istatistiksel olarak anlamlı düzeyde farklılıklar oluşturmakta mıdır?" biçimindedir. $\mathrm{Bu}$ araştırma problemine cevap aranırken, deney ve kontrol gruplarının uygulama sonrası matematik başarı puanları için öncelikle Shapiro Wilk's Testi yapılmış ve böylelikle bu grupları oluşturan katılımcıların matematik başarı puanlarının normal dağılım gösterip göstermediği analiz edilmiştir (Tablo 6).

Tablo 6. Grupların Matematik Başarı Son Test Puanlarının Normal Dağılımına ilişkin İstatistiksel Analiz Sonuçları

\begin{tabular}{ccccc}
\hline Gruplar & $\mathrm{n}$ & $\bar{x}$ & SS & Shapiro-Wilk's (p) \\
\hline Deney1 & 25 & 13.70 & 4.18 & $.030^{*}$ \\
Deney2 & 24 & 11.50 & 4.90 & $.025^{*}$ \\
Kontrol & 24 & 12.29 & 4.40 & .168 \\
\hline$* \mathrm{p}<.05$ & & & &
\end{tabular}

Araştırma gruplarını oluşturan öğrencilerin son test matematik başarı puanlarının normal dağılım gösterip göstermediğinin anlaşılması amacıyla yapılan Shapiro-Wilk testi sonuçlar1, özellikle de Deney1 $(\mathrm{p}=.030)$ ve Deney2 $(\mathrm{p}=.025)$ gruplarına ait uygulama sonrası elde edilen verilerin normal dağılım göstermediği anlaşılmıştır $(\mathrm{p}<0.05)$. Buradan hareketle, çalışma gruplarında bulunan katılımcıların uygulama sonrası matematik başarı testinden aldıkları puanlar için de parametrik olmayan analizlerin uygulanması kararlaştırılmıştır. Bu kapsamda, bu araştırma verileri için araştırmaya katılan deney ve kontrol gruplarının matematik başarı puanları üzerinden Mann Whitney-U testi yapılmış ve ulaşılan sonuçlar aşağıda sunulmuştur.

Tablo 7. Matematik Başarı Ön-Son Test Puanlarının Karşılaştırılması Amacıyla Yapılan Analiz Sonuçları

\begin{tabular}{ccccccc}
\hline Grup & Test & $\mathrm{n}$ & SiralarOrt. & $\mathrm{U}$ & $\mathrm{z}$ & $\mathrm{p}$ \\
\hline \multirow{2}{*}{ Deney1 } & Ön Test & 25 & 22.20 & \multirow{2}{*}{230.00} & -1.60 & .109 \\
& Son Test & 25 & 28.80 & & & \\
\hline \multirow{2}{*}{ Deney2 } & Ön Test & 24 & 23.71 & \multirow{2}{*}{269.00} & -.393 & .694 \\
& Son Test & 24 & 25.29 & & \\
\hline \multirow{2}{*}{ Kontrol } & Ön Test & 24 & 22.90 & \multirow{2}{*}{249.50} & -.797 & .426 \\
& Son Test & 24 & 26.10 & & \\
\hline$* \mathrm{p}<.05$ & & & & & &
\end{tabular}

Grupların uygulama öncesinde ve sonrasında matematik başarıları arasında istatistiksel olarak anlamlı düzeyde farklılıklar olup olmadığının açıklanması amacıyla gerçekleştirilen Mann Whitney-U Testi sonuçları, tüm gruplardaki katılımcıların (sırasıyla Deney1, Deney 2 ve Kontrol) ön test-son test sonuçları arasında istatistiksel olarak anlamlı düzeyde farklılıklara ulaşılamadığını göstermektedir. Sira ortalamaları dikkate alındığında ise, tüm çalışma gruplarının son test (sırasıyla 28.80, 25.29 ve 26.10) sonuçlarının ön test (sırasıyla 22.20, 23.71 ve 22.90) sonuçlarına kıyasla daha yüksek olduğu ve tüm grupların uygulama sonrası ortalama puanlarında bir artış olduğu da anlaşılmaktadır.

Aşağıda yer alan tabloda ise, araştırma gruplarındaki katılımcıların uygulama sonrası matematik başarı puanlarının karşılaştırılmasına ilişkin Mann Whitney-U testi sonuçları sunulmuştur.

Tablo 8. Grupların Matematik Başarı Son Test Puanlarının Karşılaştırılması Amacıyla Yapılan Analiz Sonuçları

\begin{tabular}{lccccc}
\hline Gruplar & $\mathrm{n}$ & Siralar Ort. & $\mathrm{U}$ & $\mathrm{z}$ & $\mathrm{p}$ \\
\hline Deney1 & 25 & 27.00 & \multirow{2}{*}{250.00} & -1.00 & .315 \\
Kontrol & 24 & 22.92 & & & \\
\hline Deney2 & 24 & 23.29 & \multirow{2}{*}{259.00} & -0.60 & .548 \\
Kontrol & 24 & 25.71 & & & \\
\hline * p $<.05$ & & & & &
\end{tabular}

Uygulama sonrasında çalışma gruplarının matematik başarıları arasında istatistiksel olarak anlamlı düzeyde bir farklılık bulunup bulunmadığının anlaşılması için gerçekleştirilen Mann Whitney-U Testi sonucuna göre, Deney1 grubu ile Kontrol grubundaki katılımciların matematik başarıları arasında istatistiksel olarak anlamlı düzeyde bir farklılığa $(\mathrm{U}=250.00, \quad \mathrm{p}=.315>.05)$ ulaşılamamıştır. Benzer şekilde, Deney2 ile Kontrol grubu öğrencilerinin uygulama sonrası matematik başarıları arasında da yine istatistiksel olarak anlamlı düzeyde bir farklılığa $(\mathrm{U}=259.00, \mathrm{p}=.548>.05)$ ulaşılamamıştır. 


\subsection{Problem Çözme Başarı Durumları}

Araştırma kapsamına alınan "Ortaokul yedinci sınıf ögrencilerine verilen üstbiliş destekli olan / olmayan problem çözme stratejileri ögretimi, öğrencilerin problem çözme başarlları açısından istatistiksel olarak anlamlı düzeyde farklılıklar oluşturmakta mıdır?" biçimindeki ikinci araştırma problemine cevap aranırken, öncelikle çalışma gruplarını oluşturan öğrencilerin başarı puanlarının normal dağılım gösterip göstermediği Shapiro Wilk's Testi ile analiz edilmiştir. Elde edilen test sonuçlarına da, aşağıda yer alan Tablo 9'da yer verilmiştir.

Tablo 9. Grupların Problem Çözme Son Test Başarı Puanlarının Normal Dağılımına ilişkin Analiz Sonuçları

\begin{tabular}{ccccc}
\hline Gruplar & $\mathrm{n}$ & $\bar{x}$ & ss & Shapiro-Wilk's (p) \\
\hline Deney1 & 25 & 13.40 & 5.47 & $.030 *$ \\
Deney2 & 24 & 10.29 & 5.57 & .147 \\
Kontrol & 24 & 8.54 & 3.95 & .112 \\
\hline$* \mathrm{p}<.05$ & & & &
\end{tabular}

Buradan anlaşılacağı gibi, çalışma gruplarını oluşturan öğrencilerin son test problem çözme başarı puanları üzerinden yapılan Shapiro-Wilk testi sonuçları, Deney1 $(p=.030)$ grubundan elde edilen uygulama sonrasi verilerin normal dağılım göstermediğine işaret etmektedir $(\mathrm{p}<.05)$. Bununla birlikte, Deney1 $(\mathrm{p}=.147)$ ve Kontrol $(\mathrm{p}=0.112)$ gruplarının uygulama sonrası verilerinin normal dağılım gösterdiği de görülmüştür. Bu nedenle, Deneyl grubundaki öğrencilerin uygulama sonrası problem çözme başarı testinden aldıkları puanlar için parametrik olmayan istatistiksel yöntemlerin uygulanması kararlaştırılmıştır. Diğer iki grup verileri için de parametrik istatistiklerin kullanılması kararlaştırılmıştır. Yapılan analiz sonuçlarına da aşağıdaki tablolarda yer verilmiştir.

Tablo 10. Deney1 Grubunun Problem Çözme Ön-Son Test Başarı Puanlarının Karşılaştııılması Amacıyla Yapılan Analiz Sonuçları

\begin{tabular}{ccccccc}
\hline Grup & Testler & $\mathrm{n}$ & Siralar Ort. & $\mathrm{u}$ & $\mathrm{z}$ & $\mathrm{p}$ \\
\hline \multirow{2}{*}{ Deney1 } & Ön Test & 25 & 20.04 & \multirow{2}{*}{176.00} & -2.654 & \multirow{2}{*}{.008} \\
& Son Test & 25 & 30.96 & & & \\
\hline$* \mathrm{p}<.05$ & & & & & &
\end{tabular}

Grupların problem çözme başarıları arasında istatistiksel olarak anlamlı düzeyde bir farklılık bulunup bulunmadığının anlaşılması için yapılan Mann Whitney-U Testi sonuçları, Deneyl grubu öğrencilerinin uygulama öncesi ve sonrası sonuçları arasında istatistiksel olarak anlamlı düzeyde bir farklılık ( $\mathrm{U}=176.00, \mathrm{p}=.008<.05)$ bulunduğunu göstermiştir. Deneyl grubundaki öğrencilerin uygulama öncesi ve sonrası problem çözme testinden aldıkları puanlarına ilişkin sıra ortalamaları dikkate alındığında da, Deney1 grubundaki öğrencilerin son test (30.96) sonuçlarının ön test (20.04) sonuçlarına kıyasla daha yüksek olduğu anlaşılmaktadır.

Deney2 ile Kontrol grubunda bulunan öğrencilerin uygulama sonrası problem çözme testinden aldıkları puanlar ise parametrik istatistiksel yöntemlerden t-testi ile değerlendirilmiş ve bu sonuçlar da aşağıda sunulmuştur.
Tablo 11. Deney2 ve Kontrol gruplarının Problem Çözme Ön-Son Test Puanlarının Karşılaştırılması için Yapılan Analiz Sonuçları

\begin{tabular}{llcrccc}
\hline Gruplar & Testler & $\mathrm{n}$ & \multicolumn{1}{c}{$\bar{c}$} & $\mathrm{SS}$ & $\mathrm{t}$ & $\mathrm{p}$ \\
\hline Deney2 & Ön Test & 24 & 7.12 & 4.13 & \multirow{2}{*}{2.60} & \multirow{2}{*}{.012} \\
& Son Test & 24 & 10.62 & 5.11 & & \\
\hline \multirow{2}{*}{ Kontrol } & Ön Test & 24 & 8.12 & .96 & \multirow{2}{*}{0.33} & .743 \\
& Son Test & 24 & 8.54 & .80 & & \\
\hline * $\mathrm{p}<.05$ & & & & & &
\end{tabular}

Yapılan incelemeler, Deney2 grubu öğrencilerinin ön-son test problem çözme başarı puanları arasında istatistiksel olarak anlamlı düzeyde bir farklılık bulunduğunu göstermektedir $\left(\mathrm{t}_{\text {Deney2/ön-sontest }}=2.60, \mathrm{p}=.012<.05\right)$.

Kontrol grubu öğrencilerinin uygulama öncesi ve sonrasındaki problem çözme başarı puanları aralarında ise istatistiksel olarak anlamlı düzeyde bir farklılığa ulaşılamamıştır ( $\left.\mathrm{t}_{\text {kontrol/ön-sontest }}=0.33, \mathrm{p}=.743>.05\right)$.

Yine Tablo 9'dan görüldüğü üzere, Deneyl grubunun son test uygulamalarından elde edilen verileri normal dağılım göstermemekle $(p=.030<.05)$ birlikte, Kontrol grubunun verileri normal dağılım göstermektedir. $\mathrm{Bu}$ nedenle, Deney1 ve Kontrol grubunda bulunan öğrencilerin uygulama sonrası problem testinden aldıkları puanlar parametrik olmayan istatistiksel yöntemlerden Mann Whitney-U Testi ile değerlendirilmiştir. Bu test sonuçlarına ilişkin bilgilere de Tablo 12'de verilmiştir.

Tablo 12. Deney1 ve Kontrol Gruplarının Problem Çözme Son Test Puanlarının Karşılaştırılması için Yapılan Analiz Sonuçları

\begin{tabular}{lccccc}
\hline Gruplar & $\mathrm{n}$ & Siralar Ort. & $\mathrm{u}$ & $\mathrm{z}$ & $\mathrm{p}$ \\
\hline Deney1 & 25 & 30.80 & \multirow{2}{*}{155.00} & -2.908 & .004 \\
Kontrol & 24 & 18.96 & & & \\
\hline * p $<.05$ & & & & &
\end{tabular}

Buradan, Deney1 ve Kontrol grubundaki katılımcıların son test problem çözme başarıları arasında istatistiksel olarak anlamlı düzeyde bir farklılık bulunduğu ( $U=155.00$, $\mathrm{p}=.004<.05)$ anlaşılmıştır. Sıra ortalamaları dikkate alındığında, Deney1 grubu katılımcılarının son test (30.80) sonuçlarının Kontrol grubundaki öğrencilerin (18.96) sonuçlarına kıyasla daha yüksek olduğu da görülmüştür.

Yine Tablo 9'dan hareketle, Deney2 ve Kontrol grubunu oluşturan öğrencilerin son test problem çözme puanlarının normal dağılım gösterdiği anlaşılmaktadır (Deney2 ve Kontrol grupları için sirasıyla $p=.147$ ve $p=.112>.05)$. Bu nedenle, öğrencilerin uygulamanın ardından problem çözme testinden aldıkları değerlerin parametrik istatistiksel yöntemlerden t-testi ile değerlendirilmesine ilişkin sonuçlar aşağıda yer alan Tablo 13'te sunulmuştur.

Tablo 13. Deney2 ve Kontrol Gruplarının Problem Çözme Son Test Puanlarının Karşılaştırılması için Yapılan Analiz Sonuçları

\begin{tabular}{ccrccc}
\hline Gruplar & $\mathrm{n}$ & \multicolumn{1}{c}{$\bar{x}$} & $\mathrm{SS}$ & $\mathrm{t}$ & $\mathrm{p}$ \\
\hline Deney2 & 24 & 10.62 & 5.11 & & \\
Kontrol & 24 & 8.54 & 3.95 & 1.57 & .121 \\
\hline$* \mathrm{p}<.05$ & & & & &
\end{tabular}

Yapilan incelemeler sonucunda, Deney2 ve Kontrol grubundaki öğrencilerin son test problem çözme başarı puanları arasında istatistiksel olarak anlamlı düzeyde farkl11ıklara ( $\left.t_{\text {Deney2-Kontrol }}=1.57, \mathrm{p}=.121>.05\right)$ ulaş1lamamıştır. Bununla birlikte, katılımciların (Deney2-Kontrol) bu testten aldıkları puan ortalamalarına bakıldığında Deney2 
grubunun ortalamasının (10.62) diğer gruba kıyasla daha yüksek olduğu da görülmüştür.

\section{4. Üstbiliş Beceri Durumları}

Araştırma kapsamına alınan "Ortaokul yedinci sınıf ögrencilerine verilen üstbiliş destekli olan / olmayan problem çözme stratejileri ögretimi, ögrencilerin üstbiliş farkındalıkları açısından istatistiksel olarak anlamlı düzeyde farklılıklar oluşturmakta mıdır?" biçimindeki üçüncü araştırma problemine cevap aranırken, ilk olarak grupları oluşturan öğrencilerin başarı puanlarının normal dağılım gösterip göstermediği Shapiro Wilk's testi ile analiz edilmiştir. $\mathrm{Bu}$ kapsamda, ilk olarak yapılan üstbiliş farkındalık puanlarına ilişkin normal dağılım sonuçlarına da Tablo 14'te yer verilmiştir.

Tablo 14. Deney ve Kontrol Gruplarının Uygulama Sonrası Üstbiliş Farkındalık Puanlarının Normal Dağılımı

\begin{tabular}{ccccc}
\hline Gruplar & $\mathrm{n}$ & $\bar{x}$ & SS & Shapiro-Wilk's (p) \\
\hline Deney1 & 21 & 204.04 & 23.46 & .902 \\
Deney2 & 22 & 206.04 & 24.80 & .243 \\
Kontrol & 21 & 189.80 & 27.61 & .209 \\
\hline$* \mathrm{p}<.05$ & & & &
\end{tabular}

Buradan görüldüğü üzere, araştırma gruplarını oluşturan katılımcıların son test Üstbiliş Farkındalık Envanteri'ne uygulama sonrasında verdikleri cevaplardan hareketle, Üstbiliş Farkındalık puanlarının normal dağılım gösterdiği anlaşılmaktadır ( $\mathrm{p}>.05)$. Bu nedenle, bu aşamada elde edilen sonuçlar bağımsız örneklem t-testi ile değerlendirilmiştir. Araştırma gruplarındaki katılımcıların Üstbiliş Farkındalık Envanteri'nden aldıkları puanların değerlendirilmesine ilişkin sonuçlar da aşağıdaki tabloda sunulmuştur.

Tablo 15. Üstbiliş Farkındalık Ön-Son Test Puanlarının Karşılaştırılması Amacıyla Yapılan Analiz Sonuçları

\begin{tabular}{llccccc}
\hline Gruplar & Testler & $\mathrm{n}$ & $\bar{x}$ & SS & $\mathrm{t}$ & $\mathrm{p}$ \\
\hline \multirow{2}{*}{ Deney1 } & Ön Test & 21 & 188.19 & 31.36 & \multirow{2}{*}{1.855} & \multirow{2}{*}{.071} \\
& Son Test & 21 & 204.04 & 23.46 & & \\
\hline \multirow{2}{*}{ Deney2 } & Ön Test & 22 & 199.59 & 30.12 & \multirow{2}{*}{1.001} & \multirow{2}{*}{.322} \\
& Son Test & 22 & 208.09 & 26.03 & & \\
\hline \multirow{2}{*}{ Kontrol } & Ön Test & 21 & 193.39 & 26.69 & \multirow{2}{*}{0.649} & \multirow{2}{*}{.520} \\
& Son Test & 21 & 188.55 & 27.23 & & \\
\hline$* \mathrm{p}<.05$ & & & & & &
\end{tabular}

Yapılan incelemeler sonucunda, öğrencilerin ön test-son test Üstbiliş Farkındalık Envanteri'nden aldıkları puanlar arasında istatistiksel olarak anlamlı düzeyde bir farklılık bulunup bulunmadığının açıklanması amacıyla yapılan t-testi sonucunda, Deneyl grubu öğrencilerinin ön-son test sonuçları arasında istatistiksel olarak anlamlı düzeyde farklılığa $\left(\mathrm{t}_{\text {Deney } 1 / \ddot{n} \text {-sontest }}=1.855, \mathrm{p}=.071>.05\right)$ ulaşılamadığ görülmüştür. Benzer şekilde, Deney2 ve Kontrol grubu öğrencilerinin aldıkları puanlar üzerinden gerçekleştirilen t-testi sonucuna göre, Üstbiliş Farkındalık Envanteri uygulama öncesi ve sonrası puanları arasında da yine istatistiksel olarak anlaml farklılıklara $\left(\mathrm{t}_{\text {Deney2/onn-sontest }}=1.001, \mathrm{p}=.322>.05\right.$ ve $\mathrm{t}_{\text {kontrol/ön-sontest }}=0.649$, $\mathrm{p}=.520>.05)$ ulaşılamamıştır. Yukarıdaki tablodan, Deney1 ve Deney2 grubunda bulunan öğrencilerin ortalama puanlarında artış olması ise dikkat çekicidir.
Aşağıda yer verilen tabloda ise, öğrenciler arasından uygulamalara katılan Deney1 ve Deney2 gruplarındaki yedinci sınıf öğrencileri ile uygulamalara katılmayan ve kendi sınıflarında kendi öğretmenleri ile matematik derslerine devam eden Kontrol grubundaki öğrencilerin üstbiliş farkındalıkları arasındaki farklılıkların ortaya koyulmasına yönelik olarak yapılmış olan bağımsız örneklem t-testi sonuçları da aşağıda açıklanmıştır.

Tablo 16. Üstbiliş Farkındalık Son Test Puanlarının Karşılaştırılması Amacıyla Yapılan Analiz Sonuçları

\begin{tabular}{cccccc}
\hline Gruplar & $\mathrm{n}$ & $\bar{x}$ & $\mathrm{SS}$ & $\mathrm{t}$ & $\mathrm{p}$ \\
\hline Deney1 & 21 & 206.04 & 26.63 & \multirow{2}{*}{2.140} & .038 \\
Kontrol & 21 & 189.04 & 24.80 & & \\
\hline Deney2 & 22 & 204.04 & 26.63 & \multirow{2}{*}{1.963} & .060 \\
Kontrol & 21 & 189.04 & 23.46 & & \\
\hline$* \mathrm{p}<05$ & & & & &
\end{tabular}

Grupların uygulama sonrasında tamamladıkları Üstbiliş Farkındalık Envanteri puanları arasında istatistiksel olarak anlamlı düzeyde bir farklılık bulunup bulunmadığını açıklamak amacıyla yapılan t-testi sonuçları, Deneyı ile Kontrol grubu öğrencilerinin üstbiliş farkındalık puanları arasında istatistiksel olarak anlamlı düzeyde bir farklılık bulunduğunu göstermiştir ( $\left.\mathrm{t}_{\text {Deney1-Kontrol }}=2.140, \mathrm{p}=.038<.05\right)$. Farklı olarak, yine uygulama sonrası Üstbiliş Farkındalık Envanteri verileri için yapılan t-testi sonucu Deney2 grubu ile Kontrol grubu öğrencilerinin üstbiliş farkındalıkları arasında istatistiksel olarak anlamlı düzeyde bir farklılığa ulaşılamadığına da işaret etmektedir ( $t_{\text {Deney2-Kontrol }}=1.963$, $\mathrm{p}=.06>.05$ ). Bununla birlikte, yapılan incelemeler Deney1 ve Deney2 grubu öğrencilerinin puanlarının aritmetik ortalamasının (sirasiyla 206.04 ve 204.04), Kontrol grubuna (189.04) kıyasla daha yüksek olduğunu göstermektedir.

\section{5. Üstbiliş Farkındalıklar ile Problem Çözme Başarıları Arasındaki İlişkiler}

Araştırma kapsamına alınan "Üstbiliş destekli olan / olmayan problem çözme stratejileri ögretimi verilen ortaokul yedinci sinıf ögrencilerinin problem çözme başarıları ile üstbiliş farkındalıkarı arasında istatistiksel olarak anlaml düzeyde ilişkiler var mıdır?" biçimindeki dördüncü araştırma problemine cevap aranırken, öğrencilerin son test üstbiliş farkındalıkları ve problem çözme başarıları arasındaki ilişkilerin ortaya koyulması amacıyla gerçekleştirilen korelasyon analizi sonuçları da, aşağıda yer alan tabloda açıklanmıştır.

Tablo 17. Üstbiliş Farkındalıklar ile Problem Çözme Başarıları Arasındaki İlişkileri Gösteren Analiz Sonuçları

\begin{tabular}{lcccc}
\hline \multicolumn{5}{c}{ Üstbiliş Fark. Envanteri-Problem Çözme T. } \\
\hline \multirow{2}{*}{ Gruplar } & \multicolumn{3}{c}{ Pearson K. } & \multicolumn{3}{c}{ Spearman K. } \\
\cline { 2 - 5 } & $\mathrm{r}$ & $\mathrm{p}$ & $\mathrm{r}$ & $\mathrm{p}$ \\
\hline Deney1 & .203 & .365 & .242 & .277 \\
Deney2 & .466 & .029 & .328 & .136 \\
Kontrol & -.087 & .707 & -.011 & .961 \\
\hline$* \mathrm{p}>.05$ & & & &
\end{tabular}

Tablo 17 incelendiğinde, araştırmaya katılan Deney1 grubu öğrencilerin üstbilişsel farkındalık ve problem çözme başarı puanları arasında pozitif yönde ve anlamlı bir ilişki olduğu görülmektedir ( $\mathrm{r}=.203)$. Korelasyon katsayısının karesi olan $\left(\mathrm{r}^{2}=.412\right)$ problem çözme başarı puanlarındaki toplam varyansın yaklaşık \%41'inin Üstbiliş̧ Farkındalıkları 
puanları ile açıklanabileceğini göstermektedir. Ayrıca, Deney2 grubu öğrencilerin farkındalık puanları ve problem çözme puanları arasında da pozitif yönde ve anlamlı bir ilişki olduğu görülmektedir $(\mathrm{r}=.466)$. Korelasyon katsayısının karesi olan $\left(r^{2}=.217\right)$ problem çözme başarı puanlarındaki toplam varyansın yaklaşık \%21'inin üstbilişsel farkındalık puanları ile açıklanabileceğini göstermiştir. Ortalamalar arası farklılığa bakıldığında, üstbiliş farkındalık puanlarının pozitif yönde değiştiği söylenebilir. Başka bir deyişle, üstbiliş farkındalık puanları değiştikçe öğrencilerin problem çözme beceri puanları da anlamlı bir şekilde değişmektedir. Ayrıca, yukarıda yer alan tablodan kontrol grubundaki katılımcıların üstbilișsel farkındalık ve problem çözme başarı puanları arasında negatif yönde ve zayıf bir ilişki olduğu görülmektedir $(\mathrm{r}=-.087)$.

\subsection{Okuma Stratejileri Üstbiliş Farkındalık Durumları}

$\mathrm{Bu}$ aşamada, araştırma kapsamında yer alan "Ortaokul yedinci sınıf ögrencilerine verilen üstbiliş destekli olan / olmayan problem çözme stratejileri ögretimi, öğrencilerin okuma stratejileri üstbiliş farkındalıkları açısından istatistiksel olarak anlaml düzeyde farklllıklar oluşturmakta mıdır?" biçimindeki araştırma problemine cevap aranirken Deney1, Deney2 ve Kontrol grubunda bulunan öğrencilerin uygulama sonrası Okuma Stratejileri Üstbilişsel Farkındalık Envanterinden aldıkları puanlar bağımlı örneklem t-testi ile değerlendirilmiş ve buna ilişkin sonuçlar da, aşağıdaki tabloda açıklanmıştır.

Tablo 18. Grupların Okuma Stratejileri Üstbilişsel Farkındalık Ön-Son Test Puanlarının Karşılaştırılması Amacıyla Yapılan Analiz Sonuçları

\begin{tabular}{lccrccc}
\hline Gruplar & Testler & $\mathrm{n}$ & \multicolumn{1}{c}{$\bar{x}$} & $\mathrm{ss}$ & $\mathrm{t}$ & $\mathrm{p}$ \\
\hline Deney1 & Ön Test & 25 & 98.44 & 19.13 & \multirow{2}{*}{3.846} & $.000^{*}$ \\
& Son Test & 25 & 116.40 & 13.38 & & \\
\hline Deney2 & Ön Test & 24 & 108.45 & 16.44 & \multirow{2}{*}{0.344} & .732 \\
& Son Test & 24 & 106.62 & 20.27 & & \\
\hline \multirow{2}{*}{ Kontrol } & Ön Test & 24 & 108.29 & 21.40 & \multirow{2}{*}{0.540} & .592 \\
& Son Test & 24 & 105.04 & 20.27 & & \\
\hline *p<.05 & & & & & &
\end{tabular}

Yapılan incelemeler sonucunda, Deneyl grubu ögrencilerinin uygulama öncesinde ve sonrasında Okuma Stratejileri Üstbilişsel Farkındalık Envanteri'nden aldıkları puanlar arasında istatistiksel olarak anlamlı düzeyde bir farklılık olduğu anlaşılmıştır (Deneylt $t_{\text {ön-son }}=3.846$, $\mathrm{p}=.00<.05)$. Ayrıca, Deney2 grubu öğrencilerinin ön-son test Okuma Stratejileri Üstbilişsel Farkındalık Envanteri puanları arasında istatistiksel olarak anlamlı düzeyde bir farklılığa ulaşılamadığını göstermiştir (Deney2-tön-son $=0.344, \mathrm{p}=.732>.05)$.

\subsection{Okuma Stratejileri Üstbiliş Farkındalıkları ile} Problem Çözme Başarıları Arasındaki İlişkiler

Araştırma kapsamına alınan "Üstbiliş destekli olan / olmayan problem çözme stratejileri öğretimi verilen ortaokul yedinci sınıf ögrencilerinin problem çözme başarıları ile okuma stratejileri üstbiliş farkındalıkları arasında istatistiksel olarak anlaml düzeyde ilişkiler var mıdır? " biçimindeki dördüncü araştırma problemine cevap aranırken, öğrencilerin son test okuma stratejileri üstbiliş farkındalıkları ve problem çözme başarıları arasındaki ilişkilerin ortaya koyulması amacıyla gerçekleștirilen korelasyon sonuçlarına da, aşağıda yer alan tabloda yer verilmiştir.

Yapılan incelemelerde, Deney1 grubunda normal dağılım varken diğer grupların normal dağılım göstermedikleri anlaşılmıştır. $\mathrm{Bu}$ nedenle de, aşağıda yer alan tabloda Spearman ve Pearson Korelasyon analizi sonuçları birarada yani aynı tablo içerisinde sunulmuştur.

Tablo 19. Öğrencilerin Son Test Okuma Stratejileri Üstbiliş Farkındalık ile Problem Çözme Başarı Puanlarıları Arasındaki İlişkileri Açıklayan Analiz Sonuçları

\begin{tabular}{lcccc}
\hline \multicolumn{3}{l}{ Okuma Stratejileri Üstbiliş F.E.-Problem Çözme Testi } \\
\hline \multirow{2}{*}{ Gruplar } & \multicolumn{3}{c}{ Pearson K. } & \multicolumn{2}{c}{ Spearman K. } \\
\cline { 2 - 5 } & \multicolumn{5}{c}{$\mathrm{p}$} & $\mathrm{p}$ \\
\hline Deney1 & .401 & .047 & .397 & .049 \\
Deney2 & .283 & .180 & .211 & .321 \\
Kontrol & -.190 & .374 & -.046 & .832 \\
\hline$* \mathrm{p}>$.05 & & &
\end{tabular}

Yukarıdaki tabloda, Deney1 grubu öğrencilerin Okuma Stratejileri Üstbiliş Farkındalık puanları ve problem çözme başarı puanları arasında pozitif yönde ve anlamlı bir ilişki olduğu görülmektedir $(\mathrm{r}=.401)$. Korelasyon katsayısının karesi olan $\mathrm{r}^{2}=.160$ değeri problem çözme başarı puanlarındaki toplam varyansın \%16'sının Okuma Stratejileri Üstbiliş Farkındalı puanları ile açıklanabileceğini göstermektedir. Ayrıca, Deney2 grubu öğrencilerin Okuma Stratejileri Üstbiliș Farkındalık puanları ve problem çözme başarı puanları arasında da pozitif yönde ve anlamlı bir ilişki olduğu anlaşılmıştır $(\mathrm{r}=.283)$. Korelasyon katsayısının karesi olan $\mathrm{r}^{2}=.08$ problem çözme başarı puanlarındaki toplam varyansın \%80'inin Okuma Stratejileri Üstbiliş Farkındalık puanları ile açıklanabileceğini göstermektedir. Ortalamalar arası farka bakıldığında da, Okuma Stratejileri Üstbiliş Farkındalık puanlarının pozitif yönde değiștiği görülmüștür. Başka bir deyişle, Okuma Stratejileri Üstbiliş Farkındalık puanı değiştikçe öğrencilerin problem çözme beceri puanları da anlamlı bir şekilde değişmektedir.

Yapılan incelemeler sonucunda, araştırmaya katılan Kontrol grubu öğrencilerin Okuma Stratejileri Üstbiliş Farkındalık puanları ve problem çözme başarı puanları arasında negatif yönde ve zayıf bir ilişki olduğu görülmektedir $(\mathrm{r}=-.190)$

\section{Tartıșma, Sonuç ve Öneriler}

Bu çalışma kapsamında, ilk olarak üstbiliş strateji destekli problem çözme öğretiminin ya da üstbiliş destekli olmayan problem çözme öğretiminin çalışma gruplarındaki öğrencilerin matematik başarıları üzerindeki etkisi araştırılmıştır.

Öğrencilerin matematik başarılarına ilişkin olarak elde edilen bulgular, deney ve kontrol gruplarının matematik başarıları arasında istatistiksel olarak anlamlı farklılıklar olmadığını göstermiştir. Bu durum, başarının birçok değişkenden etkilenen çok boyutlu bir performans olduğuna işaret etmektedir. $\mathrm{Bu}$ nedenle, başarıyı arttırmak için problem çözme stratejilerinin öğretildiği ve üstbiliş becerilerinin kullanımını destekleyen bir öğretim de tek başına yeterli olmayabilir. Bununla birlikte, çalışma gruplarının uygulama öncesi ve sonrası matematik başarı 
ortalama puanları arasında belirli bir artış olduğu dikkati çekmektedir. Puan ortalamalarındaki bu artışın Deneyl grubunda daha fazla olduğu da elde edilen bulgulardan anlaşılmıştır. $\mathrm{Bu}$ doğrultuda, yapılan uygulamaların öğrencilerin matematik performanslarında etkili olduğu söylenebilir. İstatistiksel olarak anlamlı olmamakla birlikte, bu araştırmadan elde edilen bu sonuç Özsoy (2005) tarafından yapılan çalışmanın sonucunda ulaşılan beşinci sınıfta öğrenim gören öğrencilerin problem çözme becerilerinin dersteki akademik başarılarını etkilediği sonucu ile benzerlik göstermektedir. Yine ulaşılan bu sonuç, Bağçeci, Döş ve Sarıca (2011) tarafından açıklanan ve üst bilișsel farkındalık seviyeleri ile akademik başarı arasında olumlu yönde etki bulunduğu sonucu ile de örtüşmektedir.

İkinci olarak, katılımcıların problem çözme başarıları arasında istatistiksel olarak anlamlı farklılıklar bulunup bulunmadığı incelenmiş, yapılan uygulamaların Deney1 ve Deney2 grubu öğrencilerinin problem çözme başarısını yükselttiği sonucuna ulaşılmıştır. Ayrıca, yapılan incelemelerden kontrol grubundaki katılımcıların uygulama öncesinde ve sonrasında gerçekleştirilen problem çözme başarı test sonuçları aralarında istatistiksel olarak anlamlı düzeyde bir değişim bulunmadığı anlaşılmıştır. Buradan hareketle, bu araştırma kapsamında yapılan üstbiliş destekli olan ve olmayan problem çözme strateji öğretimlerini kapsayan uygulamaların öğrencilerin problem çözme başarılarını yükselttiği söylenebilir. Bu sonuçlar da, Yazgan ve Bintaş (2005) tarafindan yapılan çalışmanın sonucunda ulaşılan strateji odaklı problem çözme öğretiminin problem çözme başarısını pozitif yönde etkilendiğinin açıklandığı çalışmanın sonuçlarını desteklemektedir. $\mathrm{Bu}$ çalışma ve ilgili literatür (Yazgan ve Bintaş, 2005; Yavuz, 2006; Ulu, Tertemiz ve Peker, 2016; Özyıldırım-Gümüş ve Umay, 2017) incelendiğinde, strateji eğitimi alan öğrencilerin problem çözme becerisini arttırdığı anlaşılmaktadır. Bu nedenle, matematik öğretiminde problem çözme stratejilerine ve bunların öğretimine farklı sınıf düzeylerinde yer verilmesi öğrencilerin matematik başarısını arttırabilir.

$\mathrm{Bu}$ araștırma kapsamında yapılan uygulamalarda katılımcıların üstbiliş farkındalıkları arasında istatistiksel olarak anlamlı farklılıklar oluşturup oluşturmadığına ilişkin olarak elde edilen bulgular, üstbiliş stratejilerinin uygulandığı Deney1 grubu öğrencileri ile üstbiliş stratejilere yer verilmeyen Deney2 ve Kontrol grubu öğrencilerinin uygulama öncesi ve sonrası üstbilişsel farkındalık durumlarının istatistiksel olarak anlamlı şekilde değişmediğini göstermiştir. Bununla birlikte, Deney1 grubu öğrencilerinin bu farkındalıklarının istatistiksel olarak anlamlı düzeyde ve olumlu yönde etkilendiği de ortaya çıkmıştır. Bu durumun, Deneyl grubunda verilen üstbiliş stratejilere dayalı eğitimden kaynaklı olduğu söylenebilir. $\mathrm{Bu}$ sonuç da, yapılan farklı çalışmalar (Pehlivan, 2012; Erdoğan, 2013) ile tutarlılık göstermektedir. Ayrıca, öğrencilerin üstbilişsel süreci içselleştirme durumlarının sonuçları etkilemesi de dikkat çekicidir. Sonuç olarak da, problem çözme strateji öğretiminin üstbiliş destekli yapılması matematik öğretiminde başarıyı önemli ölçüde etkilediği söylenebilir.

Katılımcıların üstbiliş farkındalık düzeyleri ile problem çözme başarıları arasında, gruplar açısından istatistiksel olarak anlamlı ilişkiler bulunup bulunmadığı incelenmiş ve elde edilen bulgular sonucunda Deney1 ve Deney2 grubu öğrencilerinin üstbilişsel farkındalık ve problem çözme başarı puanları arasında pozitif yönde ve anlamlı düzeyde ilişki bulunduğu açıklanmıştır. Kısacası, üstbiliş farkındalık puanı değiştikçe öğrencilerin problem çözme başarı puanları da istatistiksel olarak anlamlı bir şekilde değişmektedir. Kontrol grubu öğrencilerinin üstbilişsel farkındalık ve problem çözme başarı puanları arasında ise negatif yönde ve zayıf bir ilişki olduğu anlaşılmıştır. Ulaşılan bu sonuçlar Kaplan, Duran ve Baş (2016) tarafından yapılan araştırmanın sonucunda ulaşılan katılımcıların üstbiliş farkındalıkları ve problem çözme beceri algıları arasında pozitif yönde anlamlı bir ilişki bulunduğunu rapor ettikleri çalışmanın sonucu ile tutarlılık göstermektedir. Ayrıca Balcı (2007) da, çalışmasında ilköğretim beşinci sınıf öğrencilerinin üstbilişsel farkındalık düzeyi ile problem çözme becerisi arasında, pozitif yönde yüksek ve anlamlı bir ilişki olduğu sonucuna ulaşmıştır. Bunlara neden olarak da problem çözme yeteneğinin üst düzey bilişsel bir beceri olması gösterilebilir. Buradan hareketle, matematikte problemi çözme, strateji bilgisinin farkında olma ve anlamlı işlemler gerçekleştirmenin üstbilişsel davranışları olumlu yönde etkilediği söylenebilir. Literatürde "düşünmeyi düşünme", "öğrenmeyi öğrenme" ya da "düşünmeyi öğrenme" şeklinde karşımıza çıkan üstbiliş de bireyin kendi öğrenme sürecini bilmesi ve değerlendirmesi açısından öğrenci başarısını önemli ölçüde etkilemektedir.

Deney ve kontrol grubu öğrencilerinin okuma stratejileri üstbiliş farkındalıkları arasındaki farklılıklara ilişkin bulgular incelendiğinde de, uygulama öncesi ve sonrasında elde edilen envanter sonuçları Deney1 grubu öğrencilerinin farkındalık düzeylerinin istatistiksel olarak anlamlı biçimde arttığını göstermiştir. Bununla birlikte, Deney2 grubu öğrencilerinin uygulama öncesinde ve sonrasında yapılan okuma stratejileri farkındalık durumları ise ciddi düzeyde etkilenmemiştir. Sonuç olarak da, üstbiliş destekli problem çözme öğretiminin okuma stratejileri üstbilişsel farkındalıkta etkili olduğu söylenebilir.

Araştırmaya katılan Deney1 ve Deney2 grubu öğrencilerinin Okuma Stratejileri Üstbiliş Farkındalık puanları ile problem çözme başarı puanları arasında pozitif yönde anlamlı düzeyde bir ilişki bulunduğu da yine bu araştırma kapsamında elde edilen bulgulardan ortaya çıkmıştır. Dolayısıyla, problem çözme öğretimi verilen deney gruplarındaki öğrencilerin okuma stratejileri üstbiliş farkındalık düzeylerindeki değişimin problem çözme başarılarını istatistiksel olarak anlamlı şekilde değiştirdiğini söylemek mümkündür. $\mathrm{Bu}$ araştırmada, yapılan benzer araştırmalardan farklı olarak hem üstbiliş destekli olan problem çözme öğretimi yapılmış hem de üstbiliş destekli olmayan problem çözme öğretimine yer verilmiştir. Bu bağlamda incelendiğinde, üstbilişin gelişimi açısından iki yönteminde etkili olduğu söylenebilir. Bununla birlikte, araştırmaya katılan kontrol grubu ögrencilerinin okuma stratejileri üstbiliş farkındalık düzeyleri ile problem çözme başarıları arasında negatif yönlü zayıf bir ilişki olduğu da bu araştırma kapsamında açıklanmıştır. Ulaşılan bu sonuç da, Elia ve arkadaşları (2009) tarafından yapılan çalışmanın sonucunda ulaşılan problemi anlamadıçca bilgilerin ve uygun strateji seçebilme davranışının başarılı olmaya etkisinin olmadığı sonucu ile benzerlik göstermektedir 
(Akt. Azak, 2015). Underwood (1997) da, “anlamayı devam ettirme ve anlama yanılgılarını düzeltme, okunan bölümlerdeki sözcükleri anımsamak kadar önemli olduğuna" vurgu yapmıştır (Akt. Pehlivan, 2012). Buradan hareketle matematikte de problem çözmede de, okuma ve okuduğunu anlamanın önemli rol oynadığı sonucu çıkmaktadır. $\mathrm{Bu}$ nedenle, okuduğunu anlayan ve yorumlayan, bu sürecin farkında olan öğrencilerin problem çözme başarılarının de yüksek olması beklenen bir durumdur.

$\mathrm{Bu}$ çalışma kapsamında yapılan uygulamalar sonucunda aşağıdaki önerilere yer verilebilir:

1. Birinci araştırma problemi için bu araştırma kapsamında elde edilen sonuçlardan hareketle, ortaokul yedinci sınıf öğrencilerine verilen problem çözme ve üstbiliş destekli öğretimlerin matematik başarısını arttırmada etkili olmadığı görülmüştür. Farklı sınıf düzeylerinde benzer türden yapılacak olan araştırmalarda matematik başarısına etkisi araştırılabilir.

2. İkinci araştırma problemi için elde edilen sonuçlardan hareketle, ortaokul yedinci sınıf öğrencilerine verilen özellikle de üstbiliş destekli problem çözme öğretiminin problem çözme başarısını arttırmada etkili olduğu anlaşılmıştır. Farklı sınıf düzeylerinde benzer türden yapılacak olan araştırmalarda yine bu durum araştırılabilir. Ayrıca, bu durum üstbilişin ortaokul öğrencilerinin özellikle de problem çözme başarılarını arttırdığını göstermektedir. $\mathrm{Bu}$ nedenle de, öğretim programları öğrencilerin zengin deneyimler elde edebileceği şekilde ve üstbilişsel stratejilerle desteklenerek hazırlanabilir. Bununla birlikte, bu çalışma okul saatleri dışında gönüllülük esasına göre istekli öğrenciler ile yürütülmüştür. Daha detaylı sonuçlar alınabilmesi için okul saatleri içinde derslerle doğrudan ilişkili bir biçimde, matematik derslerinin bir parçası olacak şekilde eğitim verilebilir.

3. Diğer araştırma problemleri için elde edilen sonuçlar da, yine üstbiliş destekli problem çözme öğretiminin üstbiliş becerileri arttırmada etkili olduğuna işaret etmiştir. $\mathrm{Bu}$ nedenle, bir öğrenciye kazandırılabilmesi süreklilik esasına dayanan bu üstbiliş beceriler ilköğretimin her düzeyinde öğretim programları ile bir bütün şeklinde kazandırılabilir.

\section{Kaynaklar}

Akın, A., Abacı, R. ve Çetin, B. (2007). The validity and reliability of the Turkish version of the Metacognitive Awareness Inventory. Educational Sciences: Theory \& Practice, 7(2), 671-678.

Akyüz, G. ve Pala, N. M. (2010). PISA 2003 sonuçlarına göre ögrrenci ve sınıf özelliklerinin matematik okuryazarlığına ve problem çözme becerilerine etkisi. Illkögretim Online, 9(2), 668-678.

Aydurmuş, L. (2013). 8. Sınıf Öğrencilerinin Problem Çözme Sürecinde Kullandiğ Üstbiliş Becerilerin Incelenmesi. Master Thesis. Trabzon: Karadeniz Teknik University.

Azak, S. (2015). Ortaokul 8. Sinıf Öğrencilerinin Problem Çözmede Kullandıkları Stratejilerin ve Üstbilişsel
Davranışlarının Belirlenmesi. Master Thesis. Trabzon: Karadeniz Teknik University.

Bağçeci, B., Döş, B. ve Sarıca, R. (2011). İlköğretim öğrencilerinin üstbilişsel farkındalık düzeyleri ile akademik başarısı arasındaki ilişkinin incelenmesi. Mustafa Kemal Üniversitesi Sosyal Bilimler Enstitüsü Dergisi, 8(16), 551-566.

Bakioğlu, B., Alkış-Küçükaydın, M., Karamustafaoğlu, O., Uluçınar-Sağır, Ş., Akman, E., Ersanlı, E. ve Çakır, R. (2015). Öğretmen adaylarının bilişötesi farkındalık düzeyi, problem çözme becerileri ve teknoloji tutumlarının incelenmesi. Trakya Üniversitesi Eğitim Fakültesi Dergisi, 1(1), 22-33.

Balc1, G. (2007). İlkögrretim 5. Sinıf Öğrencilerinin Sözel Matematik Problemlerini Çözme Düzeylerine Göre Bilişsel Farkındalık Becerilerinin Incelenmesi Master Thesis. Adana: Cukurova University.

Baş, F. ve Özturan-Sağırlı, M. (2017). Türkiye'de eğitim alanında üstbiliş odaklı yapılan makalelere yönelik bir içerik analizi. Ĕgitim ve Bilim, 42(192), 1-33. http://dx.doi.org/10.15390/EB.2017.7115

Baş, F., Özturan-Sağırlı, M. ve Bekdemir, M. (2016). The metacognitive awarenesses of pre-service secondary school mathematics teachers, beliefs, attitudes on problem solving, and relationship between them. Journal of Theory and Practice in Education, 12(2), 464-482.

Baykara, K. (2011). Öğretmen adaylarının bilişötesi öğrenme stratejileri ile öğretmen yeterlik algıları üzerine bir çalışma. Hacettepe Üniversitesi Ĕ̆itim Fakültesi Dergisi, 40(1), 80-92.

Bolat, A. ve Karamustafaoğlu, S. (2019). "Vücudumuzdaki Sistemler" ünitesi başarı testi geliştirme: Geçerlik ve güvenilirlik analizi. Gazi Eğitim Bilimleri Dergisi, $5(2)$, 131-159. http://dx.doi.org/10.30855/gjes.2019.05.02.008

Büyüköztürk, S. (2007). Sosyal bilimler için veri analizi el kitabı (8. Baskı). Ankara: PegemA Yayıncılık.

Crespo, S. M., \& Kyriakides, A. O. (2007). Research, reflection and practice: To draw or not to draw: exploring children's drawings for solving mathematics problems. Teaching Children Mathematics, 14(2), 118-125.

Çakıroğlu, A. (2007). Üstbilişsel Strateji Kullanımının Okuduğunu Anlama Düzeyi Düşük Öğrencilerde Erişi Artırımına Etkisi. Doctoral Dissertation. Ankara: Gazi University.

Çıkrıkçı, Ö. ve Odacı, H. (2013). Fen lisesi öğrencilerinin bilişötesi farkındalıkları ile öz yeterlik algılarının bazı kişisel ve akademik değişkenlere göre incelenmesi. International Journal of Human Sciences, 10(2), 246-259.

Çiltaş, A. (2011). eğitimde öz-düzenleme öğretiminin önemi üzerine bir çalışma. Mehmet Akif Ersoy Üniversitesi Sosyal Bilimler Enstitüsü Dergisi, 3(5), 1-11. 
Durmuş, F. ve Özdemir, A. Ş. (2013). Çoklu zekâya dayalı öğretimin altıncı sınıf öğrencilerinin matematik dersindeki başarılarına ve üstbilişlerine etkileri. Turkish Studies, 8(12), 443-452.

Erdoğan, F. (2013). Matematik Öğretiminde Üstbilişsel Stratejilerle Desteklenen İşbirlikli Öğrenme Yönteminin, 6. Sinıf Öğrencilerinin Akademik Başarılarına, Üstbilişsel Becerilerine ve Matematik Tutumuna Etkisinin Incelenmesi. Doctoral Dissertation. Istanbul: Marmara University.

Ekiz, D. (2003). Eğitimde Araştırma Yöntem ve Metotlarına Giriş: Nitel, Nicel ve Eleştirel Kuram Metodolojileri (1.Baskı). Ankara: Anı Yayıncılık.

Evran, S. ve Yurdabakan, İ. (2013). İlköğretim 6, 7 ve 8. sınıf öğrencilerinin biliş üstü farkındalık düzeylerinin incelenmesi. Ĕ̌itim ve Öğretim Araştırmaları Dergisi, 2(1), 213-220.

Flavell, J. H. (1976). Metacognitive aspects of problem solving. In: L. B. Resnick (Ed.), The nature of intelligence (pp. 231-235). New Jersey, NY: Lawrence Erlbaum.

Garda, B. ve Temizel, M. (2016). Bilgi çağında eğitim. Selçuk Üniversitesi Sosyal ve Teknik Araştırmalar Dergisi, 12, 23-43.

Gür, H. ve Hangül, T. (2015). Ortaokul öğrencilerinin problem çözme stratejileri üzerine bir çalışma. Pegem Ĕgitim ve Ögretim Dergisi, 5(1), 95-112. http://dx.doi.org/10.30855/gjes.2019.05.02.008

Kaplan, A., Duran, M. ve Baş, G. (2016). Examination with the structural equation modeling of the relationship between mathematical metacognition awareness with skill perception of problem solving of secondary school students. Inonu University Journal of the Faculty of Education, 17(1), 1-16. http://dx.doi.org/10.17679/iuefd.17119785

Karakelle, S. ve Şentürk, C. (2006). Üst bilişsel düzeyleri yüksek ve düşük öğrencilerin ebeveyn tutumlarının incelenmesi. Psikoloji Çalışmaları, 26, 45-56.

Karslı, T. A. (2015). İlköğretim dönemindeki ergenlerde üst-biliş işlevleri ile karar verme ve denetim odağ 1 arasındaki ilişkinin incelenmesi. Elektronik Sosyal Bilimler Dergisi, 14(55), 16-31.

Koç, C. ve Karabağ, S. (2013). İlköğretim ikinci kademe (6-8. sınıf) öğrencilerinin bilişüstü yetileri ile başarı yönelimlerinin incelenmesi (Bingöl ili örneği). NWSA Education Sciences, 8(2), 308-322.

Korkut, F. (2002). Lise öğrencilerinin problem çözme becerileri. Hacettepe Üniversitesi Ĕ̆itim Fakültesi Dergisi, 22, 177-184.

Malloy, C. E., \& Jones, M. G. (1998). An investigation of African-American students' mathematical problem solving. Journal for Research in Mathematics Education, 29(2), 143-163.

Mastromatteo, M. (1994). Problem solving in Mathematics: A classroom research. Teaching \& Change, 1(2), 182-190.
Memiş, A. ve Arıcan, H. (2013). Beşinci sınıf öğrencilerinin matematiksel üstbiliş düzeylerinin cinsiyet ve başarı değişkenleri açısından incelenmesi. Karaelmas Ĕ̈itim Bilimleri Dergisi, 1, 76-93.

Mokhtari, K., \& Reichard, C. A. (2002). Assessing students' metacognitive awareness of reading strategies. Journal of Educational Psychology, 94(2), 249-259.

Naser, T. (2008). Problem Çözme Becerilerini Değerlendirmede Alternatif Yöntemler ve Illkögrretim Matematikte Örnek Uygulama. Yüksek Lisans Tezi. Van: Yüzüncü Yıl Üniversitesi.

Oğuz, A. ve Kutlu-Kalender, M. D. (2018). Ortaokul öğrencilerinin üst bilişsel farkındalıkları ile özyeterlik algıları arasındaki ilişki. Ĕgitimde Kuram ve Uygulama, 14(2), 170-186. http://dx.doi.org/10.17244/eku.319267

Okçu, V. ve Kahyaoğlu, M. (2007). İlköğretim öğretmenlerinin biliş ötesi öğrenme stratejilerin belirlenmesi. Süleyman Demirel Üniversitesi Sosyal Bilimler Enstitüsü Dergisi, 2(6), 129-146.

Özsoy, G. (2005). Problem çözme becerisi ile matematik başarısı arasındaki ilişki. Gazi Üniversitesi Gazi Ĕ̈itim Fakültesi Dergisi, 25(3), 179-190.

Özsoy, G. (2007). İlköğretim 5. Sinıfta Üstbiliş Stratejileri Öğretiminin Problem Çözme Başarısına Etkisi. Doctoral Dissertation. Ankara: Gazi University.

Özsoy, G. (2014). Problem çözme becerisi ile matematik başarısı arasındaki ilişki. Gazi Üniversitesi Gazi Ĕgitim Fakültesi Dergisi, 25(3), 179-190.

Özyıldırım-Gümüş, F. ve Umay, A. (2017). Problem çözme stratejileri öğretiminin ilköğretim matematik öğretmen adaylarının kavramsal/işlemsel çözüm tercihlerine ve problem çözme performansına etkisi. Ilkögretim Online, 16(2), 746-764. http://dx.doi.org/10.17051/ilkonline.2017.304731

Öztürk, E. (2012). Okuma Stratejileri Üstbilişsel Farkındalık Envanteri'nin Türkçe formunun geçerlik ve güvenirlik çalışması. Illköğretim Online, 11(2).

Öztürk, M., Akkan, Y. ve Kaplan, A. (2018). 6-8. sinıf üstün yetenekli öğrencilerin problem çözerken sergiledikleri üst bilişsel beceriler: Gümüşhane örneği. Ege Ĕgitim Dergisi, 19(2), 446-469. http://dx.doi.org/10.12984/egeefd.316662

Pehlivan, F. (2012). Ilköğretim Beşinci Sınıf Matematik Dersinde Üstbiliş Stratejileri Kullanımının Öğrencilerin Başarı ve Tutumlarına Etkisi. Master Thesis. Nigde: Nigde University.

Sardoğan, M. E., Karahan, T. F. ve Kaygusuz, C. (2006). Üniversite öğrencilerinin kullandıkları kararsızlık stratejilerinin problem çözme becerisi, cinsiyet, sınıf düzeyi ve fakülte türüne göre incelenmesi. Mersin Üniversitesi Eğitim Fakültesi Dergisi, 2(1), 78-97.

Schraw, G., \& Dennison, R. S. (1994). Assessing metacognitive awareness. Contemporary Educational Psychology, 19(4), 460-475. 
Seçkin-Kapucu, M. ve Öksüz R. (2015). Ortaokul öğrencilerinin üstbilişsel farkındalıklarının incelenmesi. Ĕgitim ve İnsani Bilimler Dergisi: Teori ve Uygulama, 12, 5-28.

Serin, M. K. ve Korkmaz, İ. (2018). işbirliğine dayalı ortamlarda gerçekleştirilen üstbilişsel sorgulama temelli öğretimin ilkokul 4. sınıf öğrencilerinin matematiksel problem çözme becerilerine etkisi. İlkögretim Online, 17(2), 510-531. http://dx.doi.org/10.17051/ilkonline.2018.418893

Silver, E. A., \& Cai, J. (1996). An analysis of arithmetic problem posing by middle school students. Journal for Research in Mathematics Education, 27(5), 521539.

Soylu, Y. ve Soylu, C. (2006). Matematik derslerinde başarıya giden yolda problem çözmenin rolü. Inönü Üniversitesi Eğitim Fakültesi Dergisi, 7(11), 97-111.

Şeker, T. B. (2005). Bilgi teknolojilerindeki gelişmeler çerçevesinde bilgiye erişimin yeni boyutları. Selçuk Üniversitesi Sosyal Bilimler Enstitüsü Dergisi, 377391.

Ulu, M., Tertemiz, N. ve Peker, M. (2016). Okuduğunu anlama ve problem çözme stratejileri eğitiminin ilköğretim 5. sınıf öğrencilerinin rutin olmayan problem çözme başarısına etkisi. Afyon Kocatepe Üniversitesi Sosyal Bilimler Dergisi, 18(2), 303-340.

Yang, C. T., \& Lee, S. Y. (2013). The effect of instruction in cognitive and metacognitive strategies on ninthgrade students' metacognitive abilities. New WavesEducational Research ve Development, 16(1), 4655.
Yaşa, E. (2010). Çalıșma Yaprakları Destekli Problem Çözme Stratejilerinin Öğretiminin Öğrenci Başarısina Etkisi. Master Thesis. Ankara: Gazi University.

Yavuz, G. (2006). Dokuzuncu Sinıf Matematik Dersinde Problem Çözme Stratejileri Strateji Öğretiminin Duyuşsal Özellikler ve Erişiye Etkisi. Doctoral Dissertation. İzmir: Dokuz Eylul University.

Yazgan, Y. (2007). Dördüncü ve beşinci sınıf öğrencilerinin rutin olmayan problem çözme stratejileriyle ilgili gözlemler. Ilköğretim Online, 6(2), 249-263.

Yazgan, Y. ve Bintaş, J. (2005). İlköğretim dördüncü ve beşinci sınıf öğrencilerinin problem çözme stratejilerini kullanabilme düzeyleri: Bir öğretim deneyi. Hacettepe Üniversitesi Ĕ̆itim Fakültesi, 28, 210-218.

Yıldırım, A. ve Şimşek, H. (2005). Sosyal Bilimlerde Nitel Araştırma Yöntemleri (5. bask1). Ankara: Seçkin Yayıncilik.

Yıldırım, A., Hacıhasanoğlu, R., Karakurt, P. ve Türkleş, S. (2011). Lise öğrencilerinin problem çözme becerileri ve etkileyen faktörler. Uluslararası Insan Bilimleri Dergisi, 8(1), 905-921.

Yıldız, A. ve Güven, B. (2016). Matematik öğretmenlerinin problem çözme ortamlarında öğrencilerinin üstbilişlerini harekete geçirmeye yönelik davranışları. Journal of Kirsehir Education Faculty, 17(1), 575-598. 


\section{Ek 1. Örnek Problemler}

1. Eğer her harf bir sayı için şifre ise, aşağıdaki toplama işlemi nedir? (1,2,3,6,7,9 ve 0’1 kullan.)

$$
\begin{array}{r}
\text { SUN } \\
+ \text { FUN } \\
\hline \text { SWIM }
\end{array}
$$

2. Emre'nin dairesel bir yolda giden oyuncak bir treni vardır. $\mathrm{Bu}$ yol üzerinde eşit aralıklarla dizilmiş 6 adet telefon direği vardır. Tren lokomotifinin ilk direkten üçüncü direğe gitmesi 12 saniye sürdüğüne göre aynı hızda lokomotif yolun tamamını kaç saniyede tamamlar?

3. ABCD harfleri farklı dizilişlerde yazılabilir: DCBA ya da BADC. ABCD'yi kaç farklı dizilişte yazabilirsiniz?

4. Dilek kibrit çöpleriyle ev yapıyor. 2 ev yapmak için 9 adet kibrit çöpüne ihtiyacı vardır. 5 ev sıralı yapmak için 21 adet kibrit çöpüne ihtiyacı vardır. 10 sıralı ev yapmak için kaç adet kibrit çöpüne ihtiyacı vardır?

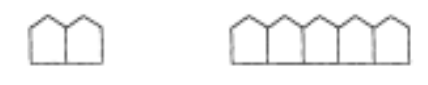

5. Bir çiftlikte sadece tavuk ve keçiler bulunmaktadır. Çiftlikteki hayvanların ayakları sayısı toplamı 144, kafaları sayısı toplamı ise 56 tür. Buna göre bu çiftlikte kaç tane keçi olduğunu bulunuz.
6. Aslı aklından bir sayı tuttu. Bu sayıyı 20 ile çarptı. 40 çıkard1. 1/4'ünü aldı ve 100 çıkard1. Böylece 80 elde etti. Aslının tuttuğu sayı kaçtır?

7. Üç eşkıya 24 litre değerli bal dolu bir fiçıyı çalarlar. Kaçarlarken yolları üzerinde bir satıcıdan 3 boş testi alırlar. Saklandıkları yere vardıklarında bu değerli balı paylaşmak isterler. Ancak boş testiler 5,11,13 litrelik testilerdir. Acaba sadece bu dört testi ile bu değerli bal üç kişi arasında eşit olarak nasıl paylaştırılır?

8. Aşağıdaki tabloyu doldurun. Tabloya göre, $2^{135}$ in birler basamağına hangi rakam geldiğini bulun?

\begin{tabular}{|l|l|l|l|l|l|l|l|l|}
\hline $\begin{array}{l}\text { 2'nin } \\
\text { kuvvetleri }\end{array}$ & $2^{1}$ & $2^{2}$ & $2^{3}$ & $2^{4}$ & $2^{5}$ & $2^{6}$ & $2^{7}$ & $2^{8}$ \\
\hline $\begin{array}{l}\text { Birler } \\
\text { basamağ1 }\end{array}$ & & & & & & & & \\
\hline
\end{tabular}

9. Bir kamyonet, tanesi $45 \mathrm{~kg}$ olan 30 çuval patates, tanesi $35 \mathrm{~kg}$ olan 25 çuval soğan taşımaktadır. Bu kamyon tartıldığında 4850 kg geldiğine göre, kamyonetin ağırlığı kaç kilogramdır? 